\title{
Achieving Sustainable Energy Security: 2030 Outlook for ASEAN, People Republic of China and India
}

\author{
Ying Fan \\ Biswa Nath Bhattacharyay
}

\author{
CESIFO WORKING PAPER NO. 5457 \\ CATEGORY 10: ENERGY AND CLIMATE ECONOMICS \\ JULY 2015
}

An electronic version of the paper may be downloaded

- from the SSRN website:

- from the RePEc website:

- from the CESifo website:

wWw.SSRN.com

Www.RePEc.org

www.CESifo-group.org/wp 


\title{
Achieving Sustainable Energy Security: 2030 Outlook for ASEAN, People Republic of China and India
}

\begin{abstract}
The rapid growth of ASEAN economies, the People's Republic of China and India (called ACI henceforth) - major drivers of Asia and the world economy_during the last five decades has caused significant strains on their scarce resources, particularly energy and contributed to serious problems of energy security, environmental degradation and climate change. In coming decades, these economies are expected to witness high growth, lack of adequate traditional energy sources, high dependence on imported energy, heavy reliance on energy-intensive industries, and rising transportation demands. In the coming decades, their energy demand may create serious challenges in terms of energy security. Adopting sustainable and innovative management practices and policies for key resources such as energy and mitigating environment and climate change problems are among major common challenges for all the ACI economies. This paper examines primarily on the ACI's sustainable energy security outlook until 2030 through an overview of the ACI's energy resources, production mix, consumption mix, emissions of greenhouse gases, and the state of the development of renewable, clean and new energy. The paper projects the ACI's energy demand and its impact on carbon dioxide emissions until 2030 under different policy scenarios using a Computable General Equilibrium (CGE) analysis. Furthermore, the paper evaluates ACI's sustainable energy security situation through examining ACI's energy self-sufficiency, dependence on imported energy, energy import diversification transportation security and energy infrastructure financing. Lastly it provides some policy recommendation to achieve sustainable energy security in ACI.
\end{abstract}

JEL-Code: Q430, Q470, R130, Q500, Q310, Q200, O530, C680.

Keywords: energy demand and security, sustainable energy, ASEAN, India and People Republic of China, environment and climate change.

Ying Fan

Institute of Policy and Management Chinese Academy of Sciences

Beijing / China

yfan@mail.casipm.ac.cn
Biswa Nath Bhattacharyay

Former Advisor

Asian Development Bank

Manila / Philippines

dr_biswa@yahoo.com

An earlier version of the paper was prepared for the Study on "ASEAN, the PRC and India: Great Transformation" of Asian Development Bank and Its Institute. The Authors thank research assistants, Linju Chen, Minglei Liu, Qinghua Bi, Qiang Ji, Shenghua Cai, Mustafa Moinuddin and Shanawez Hossain for excellent research support. 


\section{Sustainable energy security outlook for 2030}

ASEAN economies, the People's Republic of China (PRC), and India (called ACI henceforth) are large, rapidly growing, contiguous, economically integrated and projected to become the major drivers of not just the Asian economy, but also of the global economy by 2030 . Therefore, the study of sustainable energy security outlook of $\mathrm{ACl}$ is very important and topical. The rapid growth of $\mathrm{ACl}$ over the last five decades has already put serious strains on the region's scarce resources, particularly energy and contributed to serious problems of energy security, environmental degradation and climate change. The $\mathrm{ACl}$ economies already account for a disproportionate share of the global energy demands compared to their economic sizes. These economies' projected high future growth, together with its lack of adequate traditional energy sources, high dependence on imported energy, heavy reliance on energy-intensive industries, and rising transportation demands suggest that in the coming decades, they may face serious energy security problem as their energy demand will surpass their production capacities.

This paper focuses primarily on the ACl's sustainable energy security outlook until 2030. Section 1 of the paper presents an overview of the ACl's energy resources, production mix, consumption mix, emissions of greenhouse gases, and the state of the development of renewable, clean and new energy. Section 2 provides projections of the ACl's energy demand over until 2030 through developing several policy scenarios and a Computable General Equilibrium (CGE) analysis. Section 3 evaluates ACl's energy security situation through discussing ACl's energy supply, and import and export. Last section highlights the major risks and challenges facing ACl's sustainable energy security, provide policy recommendations and stresses the need for regional cooperation for ensuring the ACl's sustainable energy security in the coming decades.

\subsection{ACl energy ooverview ${ }^{2}$}

In general, the energy distribution situation is unbalanced in the $\mathrm{ACl}$ region. It has a comparatively abundant coal and natural gas reserves but it is short of crude oil. In 2010, coal reserves cover 182.02 billion tonnes in the $\mathrm{ACl}$ region, accounting for $68.5 \%$ of the total reserves in the Asia-Pacific region and $21.1 \%$ in the world. The natural gas reserve was 15.9 trillion cubic meters, accounting for $69.8 \%$ in the Asia-Pacific region and $6.0 \%$ in the world. The oil reserve was 39.7 billion barrels, accounting for $87.8 \%$ in Asia-Pacific region and only $2.87 \%$ in the world. (BP, 2011) $)^{3}$

The PRC and India have abundant coal while ASEAN is endowed with natural gas. Out of the total reserves in the $\mathrm{ACl}$ region, PRC and India accounted for $62.9 \%$ and $33.3 \%$ of coal (Figure 1.1), 37.3\% and $22.7 \%$ of oil (Figure 1.2), and $24.8 \%$ and $13.3 \%$ of natural gas (Figure 1.3), respectively as of 2010. Among ASEAN members, Indonesia, Malaysia and Viet Nam are well endowed with energy resources. The top three countries endowed with coal in ASEAN are Indonesia, Thailand and Vietnam. Natural gas in Indonesia and Malaysia covers half of the total reserves in the $\mathrm{ACl}$ region, while the oil reserves in Indonesia, Malaysia and Vietnam comprised for $36 \%$ of the total.

\footnotetext{
2 Based on BP(2011).

${ }^{3} \mathrm{ACl}$ total energy is summed by $\mathrm{ACl}$ countries from BP (2010), where a few small ASEAN countries (Cambodia, Lao PDR and Myanmar) are not included as data are not available.
} 
With respect to renewable, clean and new energy resources, PRC is endowed with 400 gigawatts (GW) of hydropower potential- highest among $\mathrm{ACl}$ countries. PRC is also rich of unconventional gas resources such as coal bed methane, with 350 trillion cubic feet estimated recoverable reserves. Among ASEAN, Viet Nam, Lao PDR and the Philippines are relatively rich in renewable energy resources. In Viet Nam, the potential for small hydropower resources (with capacity of less than 30 mega watts (MW) per site) is estimated to be about $4000 \mathrm{MW}$; total capacity of geothermal is estimated at $300-400 \mathrm{MW}$; and power from biomass is about $800 \mathrm{MW}$. Wind, solar and biogas are relatively abundant, with a potential capacity of over 2000 MW. Lao PDR is endowed with a significant hydropower resource. The Philippines has rich geothermal resources, making it the world's second-largest producer and user of geothermal energy for power generation, while other renewable energy resources (solar, wind, biomass and ocean) are estimated to have a power generation potential of more than $250,000 \mathrm{MW}$ (APERC, 2009).

Tables 1.1, 1.2 and 1.3 indicate proved coal, oil and natural gas reserves respectively in major $\mathrm{ACl}$ economies as well as the reserve and production ratio (R/P).

Figure 1.1 Regional distribution of coal in $\mathrm{ACl}$ at end of 2010

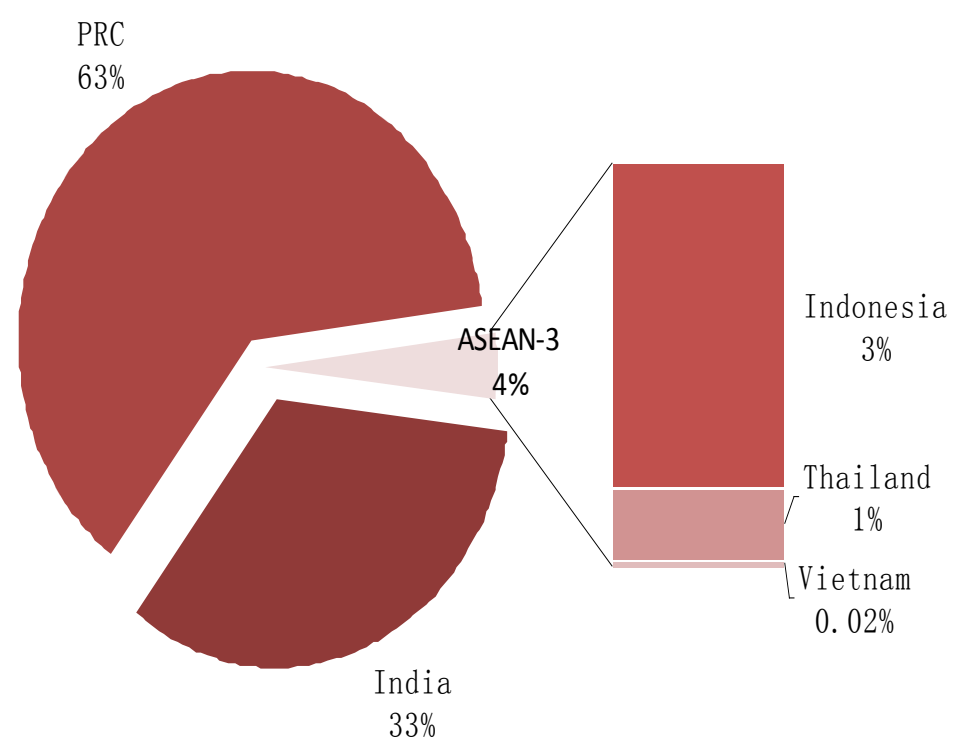

Source: BP (2011)

Table 1.1 Proved coal reserves, at end of 2010

\begin{tabular}{lrrr} 
& Million tonnes & Share of total & R/P ratio \\
Indonesia & 5530 & $0.64 \%$ & 18 \\
Thailand & 1240 & $0.14 \%$ & 69 \\
Vietnam & 150 & $0.02 \%$ & 3 \\
India & 60600 & $7.04 \%$ & 106 \\
PRC & 114500 & $13.30 \%$ & 35 \\
\hline Total World & $\mathbf{8 6 0 9 4 0}$ & & $\mathbf{1 1 8}$ \\
\hline
\end{tabular}

Source: BP (2011) 
Figure 1.2 Regional distribution of oil in $\mathrm{ACl}$ at end of 2010

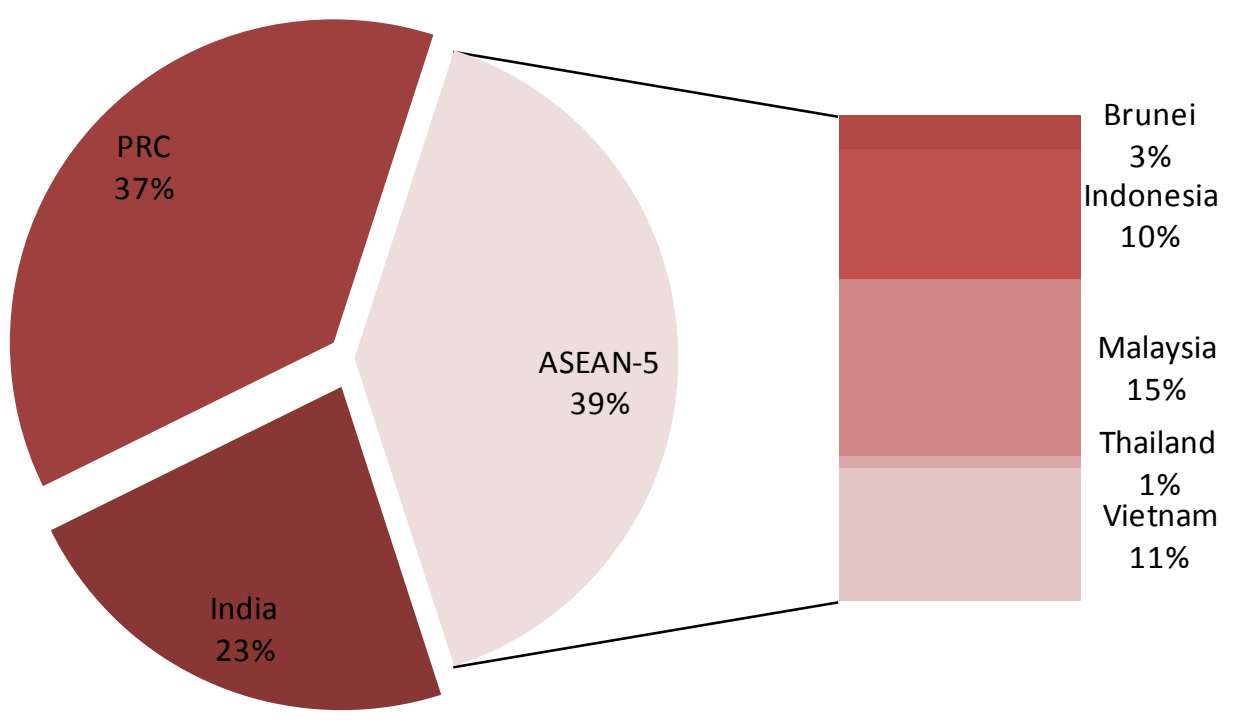

Source: BP (2011)

Table 1.2 Proved oil reserves, at end 2010

\begin{tabular}{|c|c|c|c|}
\hline & Billion barrels & Share of world & $R / P$ ratio \\
\hline Brunei & 1.1 & $0.08 \%$ & 17.5 \\
\hline Indonesia & 4.2 & $0.30 \%$ & 11.8 \\
\hline Malaysia & 5.8 & $0.42 \%$ & 22.2 \\
\hline Thailand & 0.4 & $0.03 \%$ & 3.6 \\
\hline Vietnam & 4.4 & $0.32 \%$ & 32.6 \\
\hline India & 9.0 & $0.65 \%$ & 30.0 \\
\hline PRC & 14.8 & $1.07 \%$ & 9.9 \\
\hline Total World & 1383.2 & & 46.2 \\
\hline
\end{tabular}

Source: BP(2011)

Note: R/P indicates the ration of reserves and production.

Table 1.3 Proved natural gas reserves, at end 2010

\begin{tabular}{lrrr} 
& Trillion cubic metres & Share of world & R/P ratio \\
Brunei & 0.30 & $0.16 \%$ & 24.7 \\
Indonesia & 3.10 & $1.66 \%$ & 37.4 \\
Malaysia & 2.40 & $1.28 \%$ & 36.1 \\
Myanmar & 0.30 & $0.16 \%$ & 27.5 \\
Thailand & 0.30 & $0.16 \%$ & 8.6 \\
Vietnam & 0.60 & $0.32 \%$ & 66.0 \\
India & 1.50 & $0.80 \%$ & 28.5 \\
PRC & 2.80 & $1.50 \%$ & 29.0 \\
\hline Total World & $\mathbf{1 8 7 . 1 0}$ & $\mathbf{5 8 . 6}$ \\
\hline
\end{tabular}

Source: BP(2011) 
Figure 1.3 Regional distribution of natural gas in $\mathrm{ACl}$, at end 2010

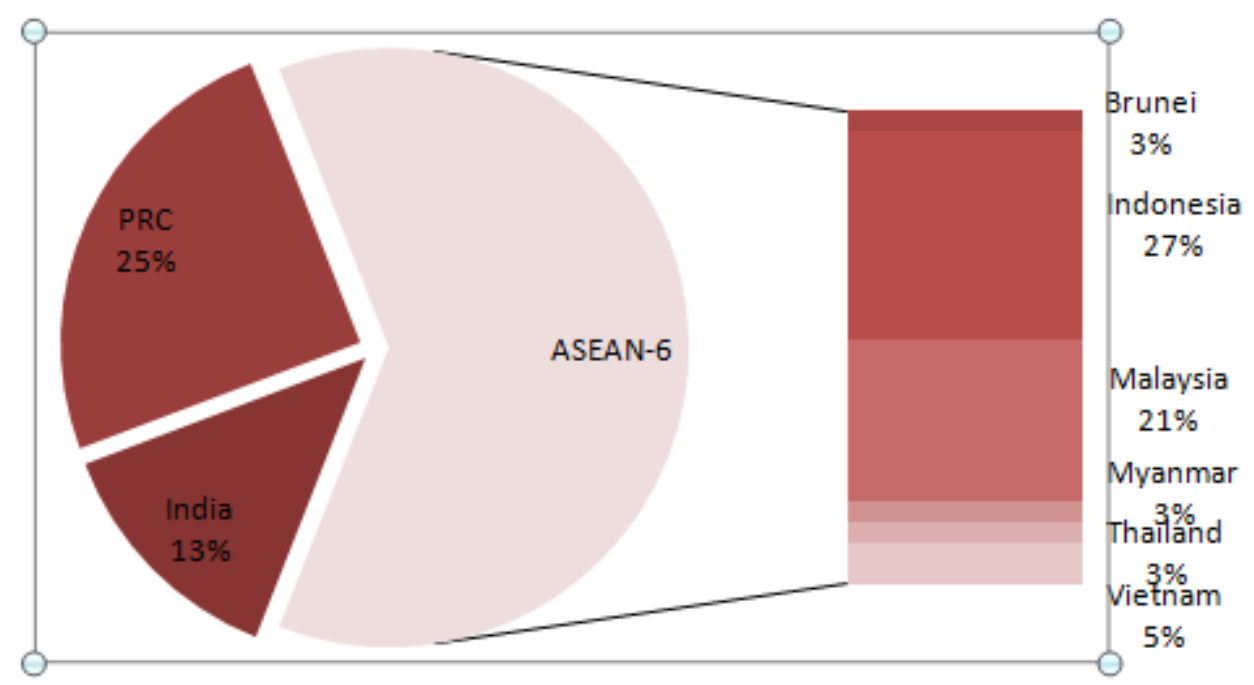

Source: BP (2011)

\subsection{Energy production mix}

The total energy production in the $\mathrm{ACl}$ region in 2008 was 2,931 million tonnes of oil equivalent (Mtoe) (IEA, 2011a). In 2008, Coal, oil and natural gas respectively cover $65 \%$ (1861 Mtoe), 12\% (369 Mtoe) and 9\% (269 Mtoe) of the total energy production in the ACI region (Figure 1.4). Table 1.4 presents ACl countries' energy production mix in 2008 (IEA, 201 and EDMC, 2011).

Figure 1.4 ACl's total primary energy production by type, 2008

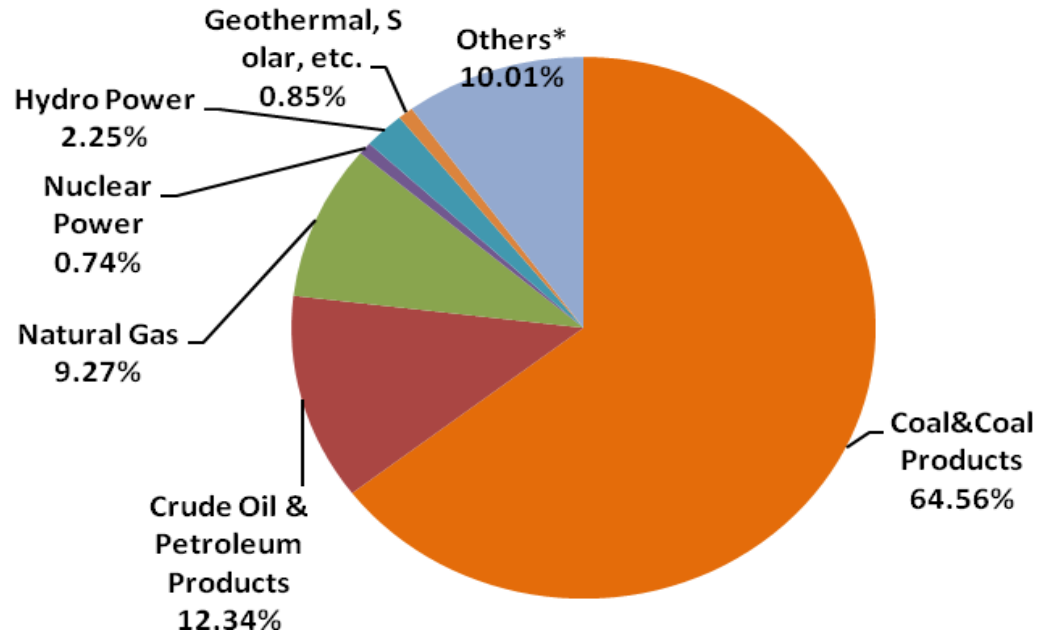

Source: EDMC (2011) \& IEA (2011a)

*Others includes Combustible Renewables and Waste 
Table 1.4 ACl's energy production Mix, 2008 (Ktoe)

\begin{tabular}{|c|c|c|c|c|c|c|c|c|c|}
\hline & PRC & India & Brunei & Indonesia & Malaysia & Myanmar & Philippines & Thailand & Vietnam \\
\hline Coal & 1471741 & 225090 & - & 134652 & 676 & 816 & 1905 & 4787 & 22275 \\
\hline Oil & 195050 & 38339 & 9346 & 56405 & 37870 & 1011 & 715 & 15182 & 15863 \\
\hline Gas & 74759 & 26299 & 11291 & 72604 & 57022 & 10464 & 3192 & 17236 & 6624 \\
\hline Nuclear Power & 17823 & 3834 & - & & - & - & - & - & - \\
\hline Hydro Power & 50326 & 9829 & - & 991 & 642 & 346 & 846 & 612 & 2235 \\
\hline Geothermal, Solar, etc. & - & 1350 & - & 7146 & - & - & 9227 & 1 & - \\
\hline Others* & 6925 & 163565 & - & 44781 & - & 10466 & 6919 & 20401 & 14724 \\
\hline Total Primary Energy production & 1816625 & 468307 & 20637 & 316579 & 96208 & 23104 & 22805 & 58218 & 61721 \\
\hline
\end{tabular}

\subsection{Energy consumption mix}

In 2008, the total energy consumption in the $\mathrm{ACl}$ region was 3074 Mtoe (IEA, 2011a) indicating a small gap between the production and the consumption. Coal, oil and natural gas respectively accounted for $57.74 \%$ (1775 Mtoe), 22.84\% (702 Mtoe) and 7.62\% (234 Mtoe) of the total energy consumption in the said year. In addition, combustible renewables and waste covered 8.4\% (258 Mtoe) of the total energy consumption (EDMC, 2011, IEA, 2011A, Figure 1.7).

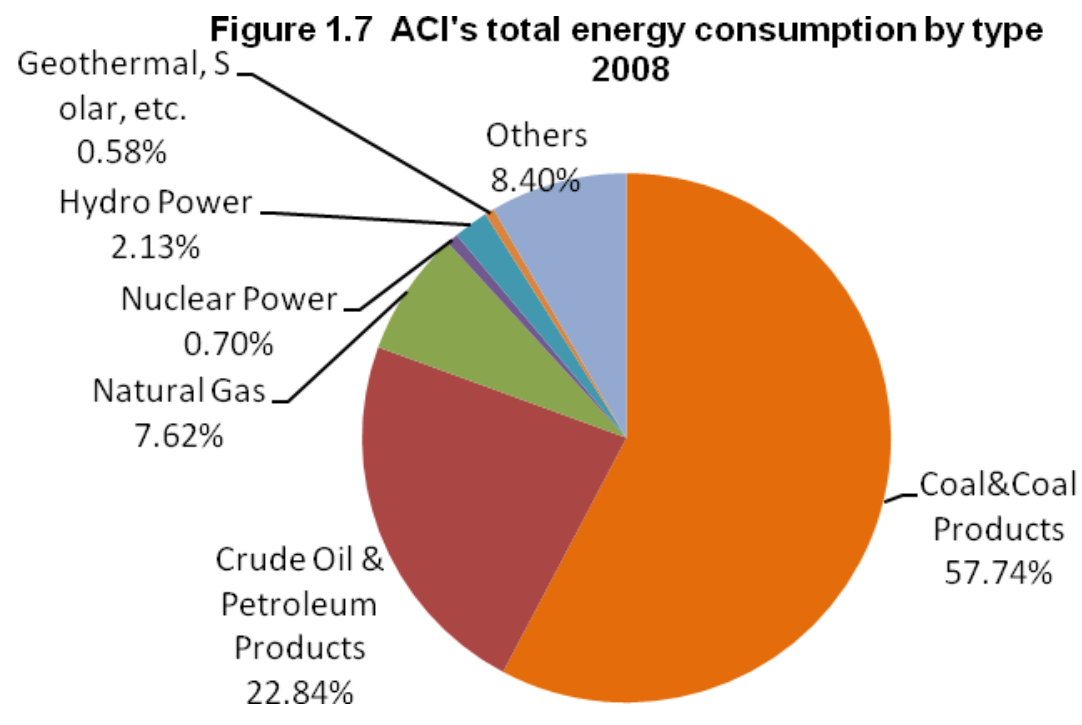

Source: EDMC (2011) \& IEA (2011a).

\subsection{ACl's emissions review ${ }^{4}$}

The carbon dioxide $\left(\mathrm{CO}_{2}\right)$ emission of the $\mathrm{ACl}$ countries was 9122 million tonnes in 2008, about $30 \%$ of the world (IEA, 2010). The ratio of $\mathrm{CO}_{2}$ emissions to GDP of the $\mathrm{ACl}$ was $1.21 \mathrm{~kg}$ $\mathrm{CO}_{2} / \mathrm{US} \$$, higher than the average of the world which was $0.73 \mathrm{~kg} \mathrm{CO}_{2} / \mathrm{US} \$$ (GDP in 2000 USD). Figure 1.8 exhibits the trends in $\mathrm{CO} 2$ emission of $\mathrm{ACl}$ economies.

\footnotetext{
${ }^{4}$ Emission data are from IEA (2010), GDP are calculated in 2000 price and official exchange rates.
} 


\section{People's Republic of China}

The $\mathrm{CO}_{2}$ emission of PRC had increased rapidly since 2001 with decreasing emissions intensity. In 2008, the emission of PRC was 6558.2 million tonnes, which was $21 \%$ of the world. The sectors of electricity and heat generation contributed the most, with $49 \%$ share of the total $\mathrm{CO}_{2}$ emissions, followed by manufacturing industries and construction, which accounted for $35 \%$. The ratio of $\mathrm{CO}_{2}$ emissions to GDP was $2.30 \mathrm{~kg} \mathrm{CO}_{2} / \mathrm{US} \$$ in the said year (Figure 1.9).

\section{India}

In India, $\mathrm{CO}_{2}$ emission had continued to grow since 2003. In 2008, India emitted 1459.1 million tonnes, nearly $5 \%$ of the global $\mathrm{CO}_{2}$ emissions. The sectors of electricity and heat generation accounted for a large share (56\%) of $\mathrm{CO}_{2}$ emissions, followed by manufacturing industries and construction accounting for 20\%. India had continuously reduced its ratio of $\mathrm{CO}_{2}$ emission to GDP since 1995, reaching $1.73 \mathrm{~kg} \mathrm{CO} / \mathrm{US} \$$ in 2008 (Figure 1.10).

Figure 1.8 Change of ACl's CO2 emissions/GDP,1995-2008 (CO2 / US dollar (2000 prices))

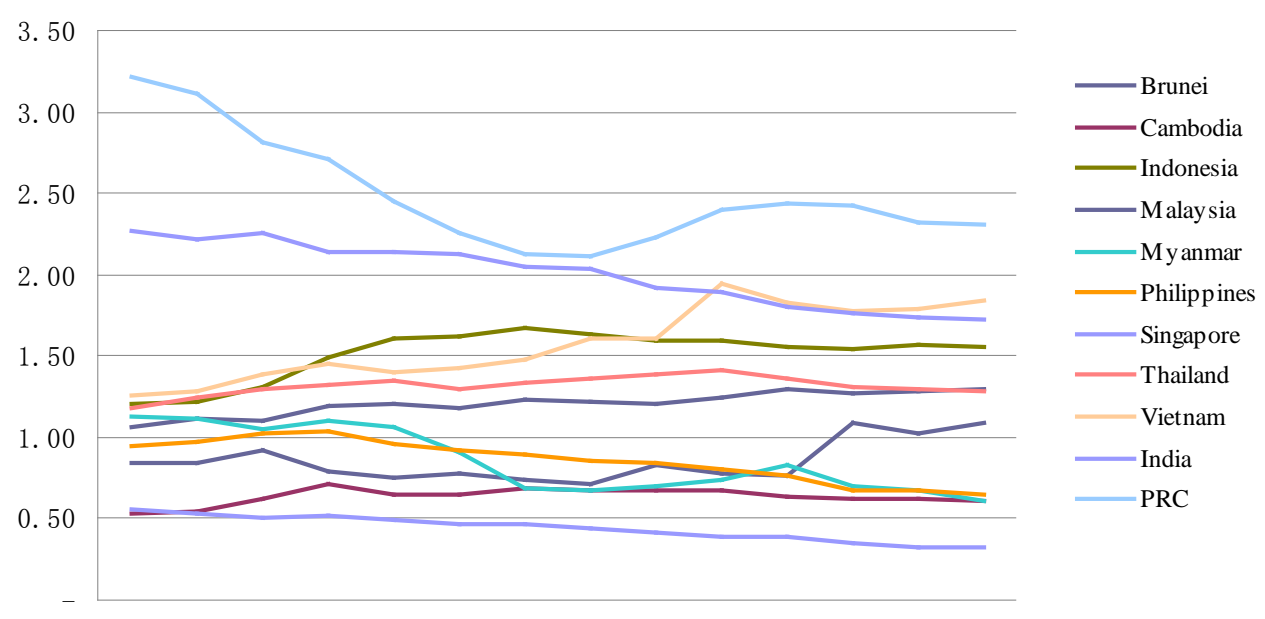

19951996199719981999200020012002200320042005200620072008

Source: IEA (2010). 


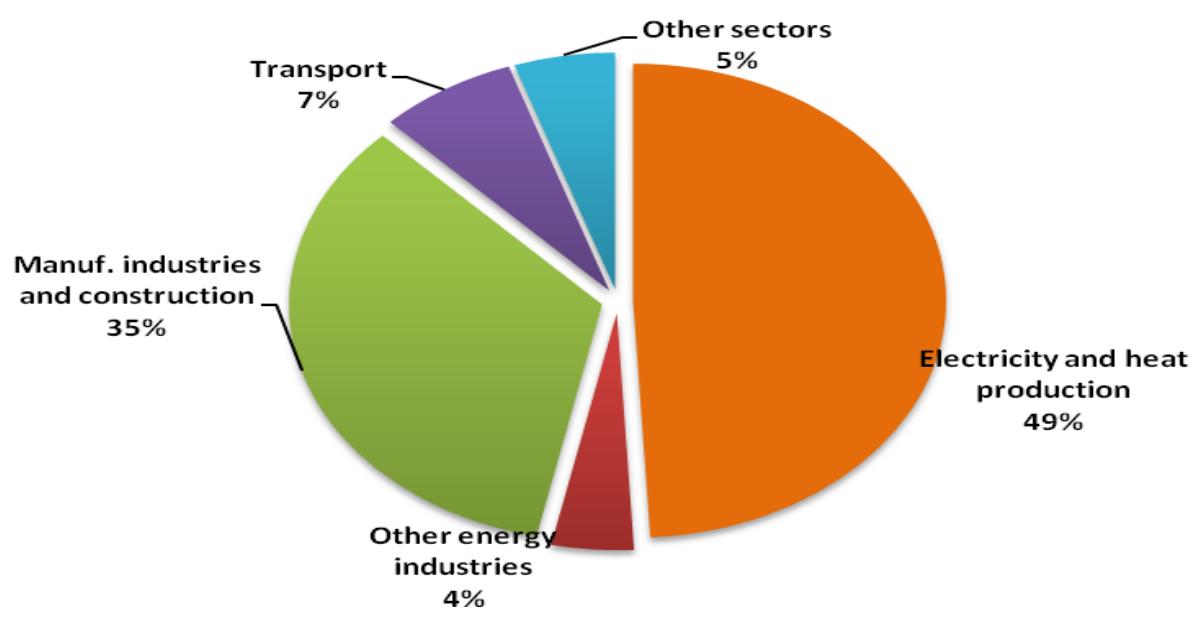

Source: IEA (2010).

\section{ASEAN}

In ASEAN, the $\mathrm{CO}_{2}$ emission had grown slowly since 2000 and reached 1060.1 million tonnes in 2008 , accounting for $3.5 \%$ of the global emissions. A large share of emissions was produced by electricity and heat generation sector, accounting for $56 \%$, followed by manufacture industry and construction sector (29\%); and transport sector (22\%). Table 1.2 presents the $\mathrm{CO} 2$ emissions and emissions intensity in ASEAN countries. Figure 1.11 exhibits emissions of ASEAN countries by sector.

Figure 1.10 India:CO2 emission by source (2008)

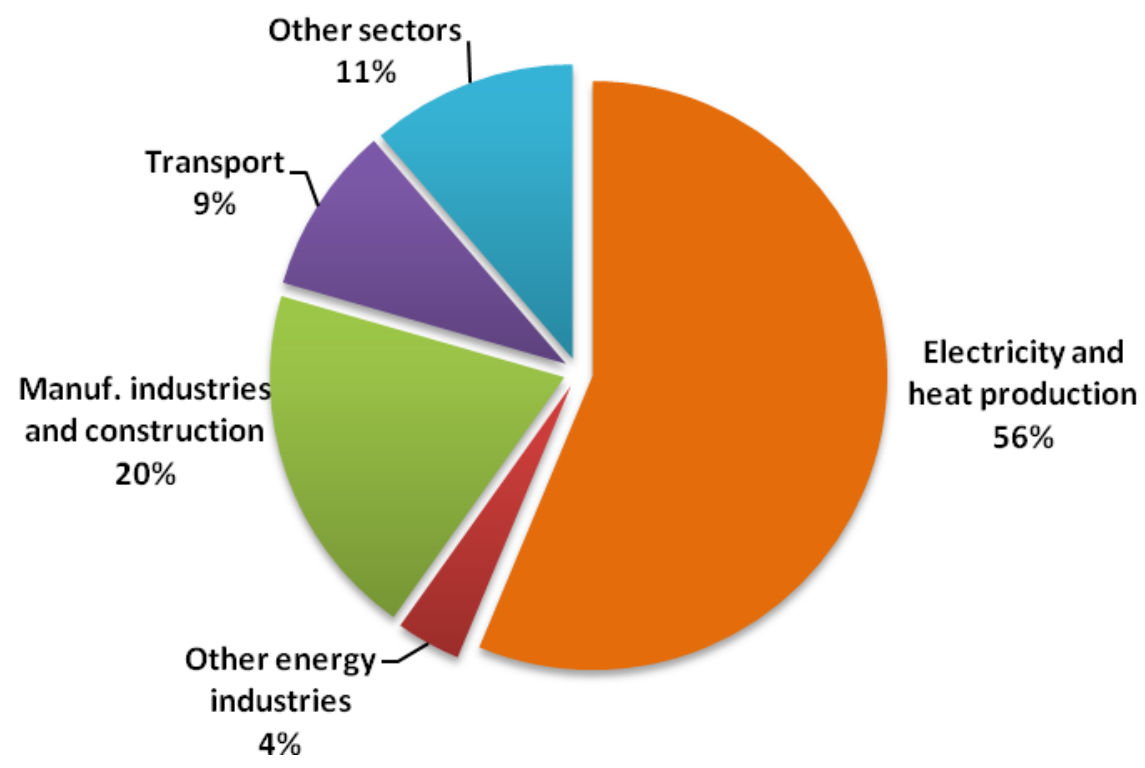

Source: IEA (2010) 
Table 1.5 ASEAN's $\mathrm{CO}_{2}$ emissions and emission intensity using exchange rate, 2008

\begin{tabular}{lrrr} 
& \multicolumn{2}{c}{$\begin{array}{c}\text { CO2 emissions } \\
\text { million tonnes of } \mathrm{CO} 2 \text { share of total worldkg }\end{array}$} \\
Bro2 / US dollar (2000 prices) \\
Cambodia & 8.9 & $0.03 \%$ & 1.1 \\
Indonesia & 4.6 & $0.02 \%$ & 0.6 \\
Malaysia & 386.1 & $1.29 \%$ & 1.6 \\
Myanmar & 191.5 & $0.64 \%$ & 1.3 \\
Philippines & 12.4 & $0.04 \%$ & 0.6 \\
Singapore & 73.8 & $0.25 \%$ & 0.7 \\
Thailand & 33.9 & $0.11 \%$ & 0.3 \\
Vietnam & 246.1 & $0.82 \%$ & 1.3 \\
ASEAN & 102.8 & $0.34 \%$ & 1.8 \\
\hline
\end{tabular}

Source: IEA (2010).

Indonesia, Thailand and Malaysia are the top three $\mathrm{CO}_{2}$ emitters in ASEAN. The sector of electricity and heat generation emitted the largest in most countries, while manufacture industries and construction sector produced the largest emissions in Viet Nam. The ratio of $\mathrm{CO}_{2}$ emissions to GDP presented a decreasing trend in Singapore, Philippines, Indonesia and Thailand, while Singapore had the smallest emission intensity. In contrast with these countries, the ratio of $\mathrm{CO}_{2}$ to GDP had been slowly ascending in Malaysia and Viet Nam.

Figure 1.11 ASEAN $\mathrm{CO}_{2}$ emissions by sector, 2008 (million tonnes of $\mathrm{CO}_{2}$ )

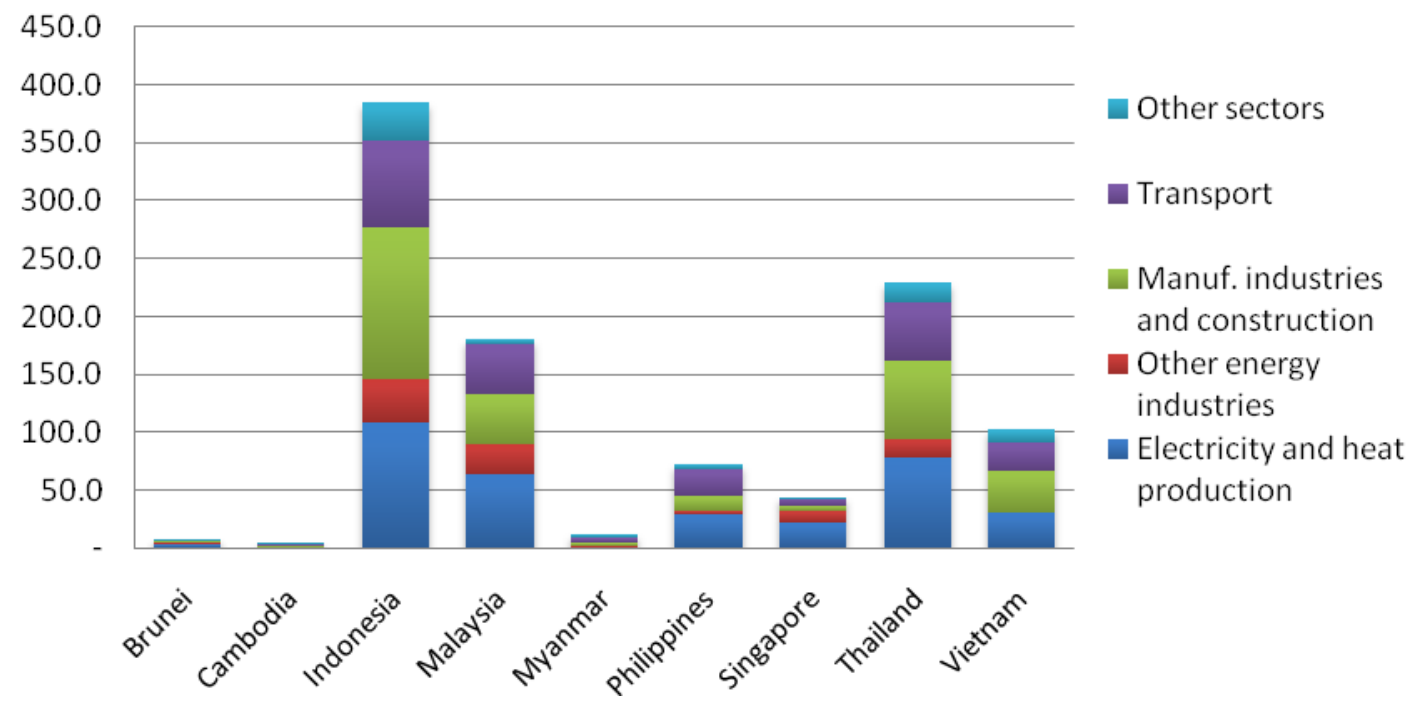

Source: IEA (2010)

\subsection{Development of renewable, clean and new energy ${ }^{5}$}

In recent years, renewable, clean and new energy of $\mathrm{ACl}$ economies had developed rapidly and become one of the fastest growing regions in the world. Due to resource constraints, the renewable, clean and new energy development in each country exhibits distinctive characters.

\footnotetext{
${ }^{5}$ Data are taken from IEA(2011a).
} 
As a whole, hydro is the largest source of renewable in the $\mathrm{ACl}$ region. Specifically, PRC and India have relatively fast development of wind and nuclear energy, while Philippines and Indonesia are rich in geothermal resources, and Thailand's biomass accounted for a large proportion of its renewable, clean and new energy. In 2008, hydropower accounted for $15.7 \%$ of the total power generation in the $\mathrm{ACl}$ region. Nuclear was the second-largest source of new energy, which accounted for $1.7 \%$ of the total power generation. At the end of 2009, ACl's cumulative installed wind turbine capacity was $36680 \mathrm{MW}$, cumulative installed geothermal power capacity was $2503.4 \mathrm{MW}$, and cumulative installed photovoltaic (PV) power was 438.3 MW, accounting for $22.9 \%, 20 \%, 1.9 \%$ of the total installed capacity, respectively (Figure 1.12) .

\section{People Republic of China}

In PRC, claen and renewable energy sources have developed rapidly. In particular, achievements in the development hydropower and wind are prominent. The proportion of non-fossil energy electricity installed capacity and electricity generation had increased in recent years. At the end of 2009, the national 6000 kilowatts and above non-fossil energy electricity installed capacity (hydro, nuclear, wind power, solar, geothermal, tidal energy, biomass and waste energy, waste heat and pressure energy and other resources recycling) totaled 222 million kilowatts, accounting for $25.4 \%$ of total electricity installed capacity (874 million kilowatts). Total electricity generation from renewable sources was 669 terra watt-hour (TWh) in 2009, which was $18 \%$ of total electricity production.

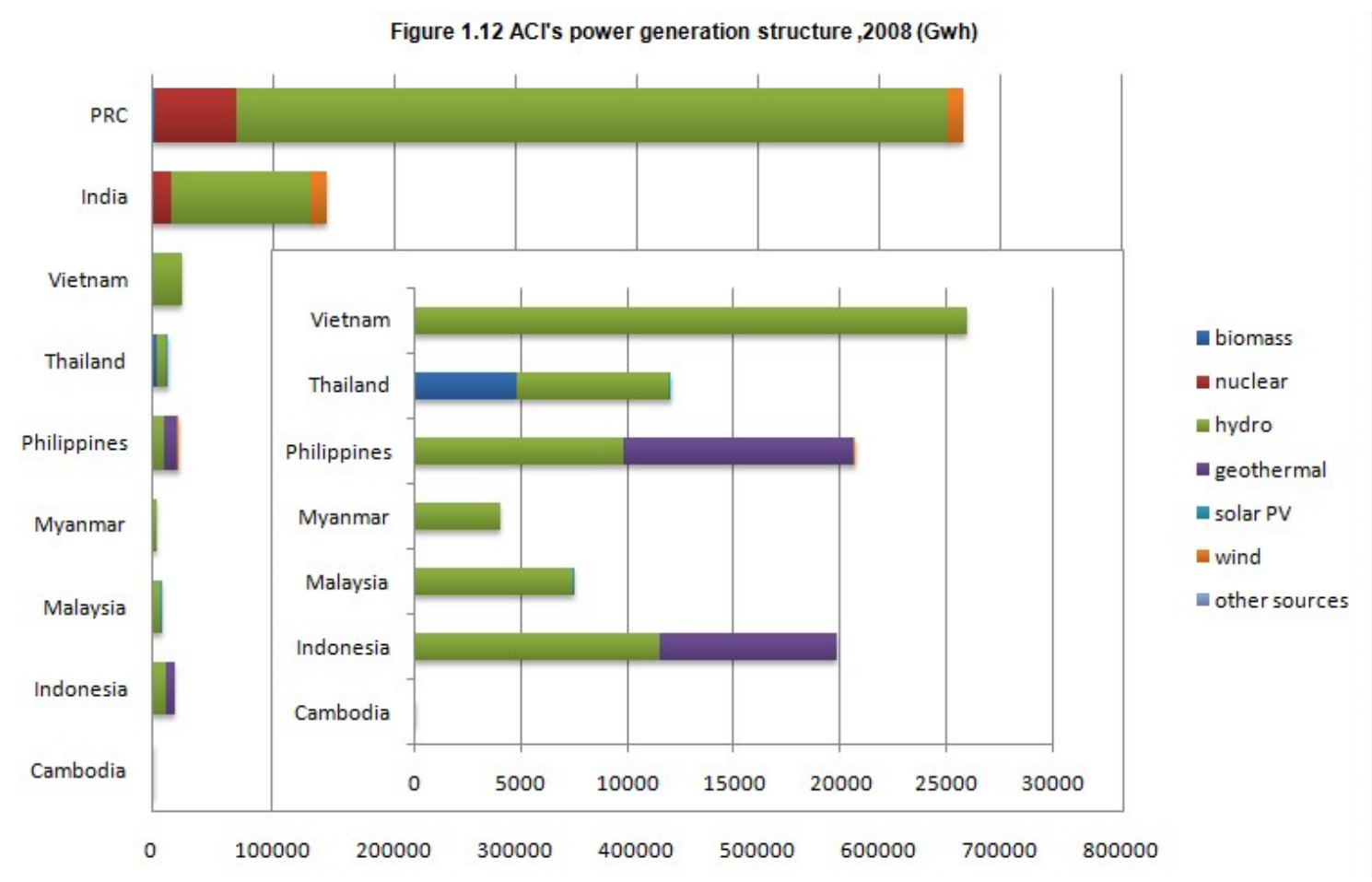

Source:IEA (2011a)

Source:IEA,http://www.iea.org/stats/prodresult.asp?PRODUCT=Electricity/Heat

The PRC was the world's top investor in renewable energy projects in 2010, totaling around US $\$ 120$ billion to US $\$ 160$ billion investment between 2007 and 2010.Since 2008, PRC has 
introduced a series of financial and tax policies to boost the development of renewable energy power projects, such as (i) the renewable energy law, and the medium and long-term development planning for renewable energy; (ii) wind power equipment industry special funds management; (iii) the interim renewable energy electricity prices and the cost-sharing management pilot scheme; and (iv) the stimulation program in the field of solar energy with increasing financial support for the photovoltaic power generation industry.

\section{India}

India's total electricity generation from renewable sources was 145 TWh in 2008, and this aacounted for $17.4 \%$ of India's electricity production. The Indian policies of promoting the development of renwable, clean and new energy sources include: (i) subsidies for renwable and new energy policies and incentive system; (ii) setting up of a special new energy management authority; (iii) increasing the investment in new energy technology and determining the routes of new energy technologies; and (iv) enforcing international cooperation and making effort in the development of new energy.

\section{ASEAN}

The Indonesia's potential geothermal and biomass electricity generation is large. The proportion of new and renewable energy electricity generation reached $13.3 \%$ of the total electricity prodcution in 2008.

Meanwhile, new. clean and renewable energy electricity generation of was Malaysia 7.46 Twh in 2008 , accounting for $7.7 \%$ of the total electricity generation. Almost all new,clean and renewable energy electricity generation came from hydroelectricity (7459 Gwh), as the remaining small amount was from solar energy electricity generation (1Gwh).

The Philippines' new,clean and renewable energy generation capacity was 20.6 GWh in 2008 , accounting for $34 \%$ of the total electricity generation-the highest proportion of new and renewable energy electricity generation in the $\mathrm{ACl}$ region. In 2009, geothermal electricity installed capacity was $1904 \mathrm{MW}$, accounting for $17.8 \%$ of the world's total geothermal electricity installed capacity ranking second in the world after the United States. The total estimated potential of untapped geothermal resource is about $2600 \mathrm{MW}$. The geothermal electricity generation of the country was 10.7 gigawatt hour (GWh) in 2008, which accounted for $17.6 \%$ of its total electricity generation. (IEA, 2011a)

Viet Nam is relatively rich in renewable energy resources including small hydro, solar, biomass, wind and geothermal. Combustible renewable and waste composed the largest portion $(41.8 \%)$ of energy consumption in 2008. The share of hydroelectricity generation ranked second in the $\mathrm{ACl}$ region. In 2008, hydroelectricity generation was about $26 \mathrm{GWh}$, accounting for $35.6 \%$ of the total. However, despite the high potential of renewable energy resources, their contribution in electricity production is still negligible. Viet Nam's target is to increase the share of renewables in total electricity production to $5 \%$ or higher by 2025 .

\section{Projection of $\mathrm{ACl}$ energy demand to $\mathbf{2 0 3 0}$}

For effective management of the energy security, it is essential to estimate the energy demand which will be discussed in the subsequent sections. 


\subsection{Prediction methodology}

\section{People's Republic of China}

A dynamic Computable General Equilibrium (CGE) model is employed to forecast energy demand in PRC. This model is an enhancement and extension of the earlier MONASH model developed by the Center of Policy Studies (Dixon and Rimmer, 2002) which describes behaviors of economic agent and linkages between sectors of economy, and between PRC and the rest of the world. The core part of our CGE model contains widely accepted economic theories such as consumer and producer optimization behaviors. It includes 138 industry sectors, three input factors (labor, capital and land), six economy entities (enterprise, household, governments, investments, exports and stocks), six basic modules (production module, demand module, distribution module, trade module, price module, dynamic module). There are six energy production sectors: Mining and Washing of Coal, Extraction of Petroleum Extraction of Natural Gas, Processing of Petroleum and Nuclear Fuel, Coking, Production and Supply of Electric Power and Heat Power, Production and Distribution of Gas. The extensions of our model from the standard MONASH Model are discussed in the following section.

Firstly, we change and improve the nested production structure of MONASH Model, in the production structure, we aggregate various energy to form an energy beam according to the CES (Constant Elasticity of Substitution) function, then the production model can support substitution in production in different energy commodities and between energy commodities and primary factors, which is not considered in the standard MONASH production system. Secondly, our model estimates the elasticity of substitution between different energy sources and primary factors through analyzing the historical data on energy. Thirdly, our CGE model includes the carbon tax module, which is used to study the impacts of adding carbon tax on the PRC's economy and energy demand. Lastly, the Carbon Emission Module considers not only the carbon emissions of fossil energy, but also the process emissions of the cement sector.

In the intensive low-carbon scenario, we achieve the emission target in 2020 through levying a carbon tax, especially by imposing carbon tax on fuel combustion emissions (coal, natural gas, and refined oil) in the form of consumption tax, and in the form of production tax on the process emissions of the cement production. The CGE model characterizes the dynamic module to describe the competitive structure by introducing capital accumulation and labor market adjustments (see Table 2.1).

\section{India}

We use the IEA's (2011b) predictions on India's energy demand based on its World Energy Model (WEM). Three different policy scenarios were presented by IEA (2011b): the 
Current Policies scenario ${ }^{6}$, the New Policies scenario ${ }^{7}$, and the 450 scenario $^{8}$. Under the Current Policies Scenario was India's Extensive Economic Scenario, and any emission abatement pledges or measures were not taken into account. Meanwhile, considering India's abatement pledge, $\mathrm{CO}_{2}$ intensity was assumed to be reduced by $20 \% \sim 25 \%$ in 2020 compared to the 2005 level and these were considered under the New Policies Scenario with 20\% reduction, and under the 450 Scenario with $25 \%$ reduction. The New Policies Scenario and the 450 Scenario were regarded as the Reference Scenario and the Enhanced Low-carbon Scenario in this study, respectively (see Table 2.1).

\section{ASEAN}

We use the energy demand predictions for ASEAN countries by ADB (2009) in its report "Energy Outlook for Asia and the Pacific". However, it did not predict the effects of climate and environment place policies on the future energy demand of ASEAN. The IEA (2009) predicted the energy demand for ASEAN in two different scenarios----the Reference Scenario and the 450 Scenario. In section 2.3 of this study, the IEA prediction results will also be presented to analyze the impact of the climate and environmental policies on the energy demand of ASEAN.

Table 2.1 Principal policy assumptions for PRC and India by scenario

\begin{tabular}{|c|c|c|c|}
\hline & $\begin{array}{c}\text { Extensive Economic } \\
\text { Scenario }\end{array}$ & Reference Scenario & $\begin{array}{c}\text { Enhanced Low-carbon } \\
\text { Scenario }\end{array}$ \\
\hline PRC & $\begin{array}{l}\text {-The present policies } \\
\text { would not be carried out } \\
\text { completely; } \\
\text { - The government will not } \\
\text { carry out new effective } \\
\text { low-carbon policies. } \\
\text { - PRC will not transform } \\
\text { structure of the economy } \\
\text { effectively. }\end{array}$ & $\begin{array}{l}\text {-The national policy that } \\
\text { PRC issued will not } \\
\text { change and will be } \\
\text { carried out completely. } \\
\text { - The carbon emission } \\
\text { intensity of PRC in } 2020 \\
\text { will be reduced by } 40 \% \\
\text { compared with the } 2005 \\
\text { level. }\end{array}$ & $\begin{array}{l}\text {-PRC will begin to impose } \\
\text { carbon tax from } 2012 \\
\text {-Renewable energy will be } \\
\text { developed in a more } \\
\text { rapid speed } \\
\text {-The sustainable } \\
\text { development of } \\
\text { low-carbon economy will } \\
\text { be accelerated and the } \\
\text { transformation of }\end{array}$ \\
\hline
\end{tabular}

\footnotetext{
${ }^{6}$ The Current Policies Scenario takes into account those measures that governments had formally adopted by the middle of 2010 in response to and in pursuit of energy and environmental policies, but takes no account of any future changes in government policies and does not include measures to meet any energy or climate policy targets or commitments that have not yet been adopted or fully implemented.

${ }^{7}$ The New Policies Scenario takes account of the broad policy commitments that have already been announced and assumes cautious implementation of national pledges to reduce greenhouse-gas emissions by 2020 and to reform fossil-fuel subsidies.

${ }^{8}$ The 450 Scenario assumes implementation of the high-end of national pledges and stronger policies after 2020, including the near-universal removal of fossil-fuel consumption subsidies, to achieve the objective of limiting the concentration of greenhouse gases in the atmosphere to 450 parts per million of CO2-equivalent and global temperature increase to $2^{\circ}$ Celsius.
} 
industrial structure will come true.

\begin{tabular}{|c|c|c|c|}
\hline India* & $\begin{array}{l}\text { - Trading of renewable } \\
\text { energy certificates; } \\
\text { - Measures under } \\
\text { national solar mission } \\
\text { and national mission } \\
\text { on enhanced energy } \\
\text { efficiency (Perform } \\
\text { Achieve and Trade } \\
\text { [PAT] scheme for } \\
\text { industry).. }\end{array}$ & $\begin{array}{l}\text { - A } 20 \% \text { reduction in CO2 } \\
\text { intensity compared } \\
\text { with the } 2005 \text { level by } \\
2020 ; \\
\text { - Auto fuel-efficiency } \\
\text { standards; } 20 \mathrm{GW} \text { of } \\
\text { solar energy } \\
\text { production capacity by } \\
2022 \text {. }\end{array}$ & $\begin{array}{l}\text { - A } 25 \% \text { reduction in CO2 } \\
\text { intensity compared with } \\
\text { the } 2005 \text { level by } 2020 ; \\
\text {-Expanded feed-in tariffs } \\
\text { for renewables. }\end{array}$ \\
\hline
\end{tabular}

\footnotetext{
* India's Extensive Economic Scenario, Reference Scenario and Enhanced Low-carbon Economic Scenario are equivalent to the Current Policies Scenario, the New Policies Scenario and the 450 Scenario of IEA (2011) respectively.

Source: IEA (2011b); and authors' analysis.
}

\subsection{Prediction results of alternative scenarios to 2030}

\section{People Republic of China}

In 2005, the total primary energy demand was 1622.8 Mtoe while its non-fossil energy sources (excluding traditional biomass) accounted for $6.8 \%$, with $\mathrm{CO}_{2}$ emission intensity of $2973.5 \mathrm{t}$ /million US dollars (constant 2000 US \$). In the Reference Scenario, the share of non-fossil energy in the total primary energy demand is projected to reach $11.8 \%$ while the $\mathrm{CO}_{2}$ emission intensity will decrease to $1782.4 \mathrm{t} /$ million dollars in 2020 lower by $40.1 \%$ compared to the level of 2005. Total primary energy demand is projected to reach 3607 Mtoe in 2020 and 4320 Mtoe in 2030, with an average annual rate of $4.0 \%$ from 2005 to 2030. To meet the rising electricity demand, PRC will continue to rely on coal because it is the most cost-competitive option among all fuel types. Coal demand is projected to increase to 2316.1 Mtoe in 2030 with an average annual rate of $2.9 \%$. However, the proportion of coal in total primary energy will decrease from $70.4 \%$ in 2005 to $53.6 \%$ in 2030 . Oil demand will reach 752.5 Mtoe in 2030 with an average annual rate of $3.4 \%$, which is largely boosted by the transport sector.

In the Reference Scenario, improving energy mix will become very important in order to achieve the $40 \%$ reduction of the $\mathrm{CO}_{2}$ intensity in 2020 . The annual growth rates of natural gas and non-fossil energy are projected to be $9.1 \%$ and $8.6 \%$, respectively. The energy intensity will decrease from 857.1 toe/million dollars in 2005 to 353.8 toe/million dollars in 2030 with an average annual rate of $3.5 \%$ decline.

In the Extensive Economic Scenario, primary energy demand is projected to reach 4049.4 Mtoe in 2020 and 4806.8 Mtoe in 2030, with an average annual rate of 4.4\% from 2005 to 2030. In 2020, the $\mathrm{CO}_{2}$ emission intensity of PRC is projected to be $1945.2 \mathrm{t} /$ million dollars reduced by $34.6 \%$ compared to that of 2005 , and the share of non-fossil energy in total primary energy will increase to $10.1 \%$. PRC will fail to achieve its abatement pledge (see table 2.2). 


\section{India}

According to the IEA (2011b), total primary energy demand in India will increase along with the country's high economic growth. In the Reference Scenario, India will achieve the low end of its abatement pledge, i.e, $\mathrm{CO}_{2}$ intensity will be reduced by $20 \%$ in 2020 compared with the 2005 level. Total energy demand will increase from 669 Mtoe in 2009 to 1256 Mtoe in 2030 with an average annual rate of 3.1\%. In the Extensive Economic Scenario, India is assumed to maintain current energy policies and not to introduce further climate policies. Under this case, the total energy demand in India will be 1372 Mtoe in 2030 with an average growth rate of $3.4 \%$ per annum, which has increased by $9.2 \%$ to that of the Reference Scenario.

Fossil fuels continue to dominate energy consumption. Total fossil energy was $488 \mathrm{Mtoe}$, accounting for $72.9 \%$ of total primary energy in 2009. In the Reference Scenario, total fossil energy will grow at 3.3\% per annum to 956 Mtoe in 2030. The share of the fossil energy in primary energy demand will increase to $76.1 \%$ in 2030. Coal, oil and natural gas will increase to 544 Mtoe, 288 Mtoe and 124 Mtoe in 2030 with the average annual rate of $3.2 \%, 2.8 \%$ and 4.5\%, respectively. In the Extensive Economic Scenario, total fossil energy is projected to grow at $3.9 \%$ per annum to 1372 Mtoe in 2030 which is $14.4 \%$ higher than that of the Reference Scenario and accounts for $79.8 \%$ of total primary energy demand. Both coal and oil will grow quickly with an average annual rate more than $3.7 \%$.

The Special Report of World Energy Outlook 2011(IEA, 2011c) showed a new scenario 'GAS Scenario' under which India's primary natural gas demand will increase to 87.9 Mtoe in 2020 and 148.9 Mtoe in 2030-indicating a more important role of natural gas in India's energy demand (Table 2.3).

Table 2.2 PRC's primary energy demand and alternative $\mathrm{CO}_{2}$ emission scenario

\begin{tabular}{|c|c|c|c|c|c|c|c|}
\hline & \multirow[b]{2}{*}{2005} & \multicolumn{2}{|c|}{$\begin{array}{l}\text { Extensive } \\
\text { Economic } \\
\text { Scenario }\end{array}$} & \multicolumn{2}{|c|}{$\begin{array}{l}\text { Reference } \\
\text { Scenario }\end{array}$} & \multicolumn{2}{|c|}{$\begin{array}{l}\text { Enhanced } \\
\text { Low-carbon } \\
\text { Scenario }\end{array}$} \\
\hline & & 2020 & 2030 & 2020 & 2030 & 2020 & 2030 \\
\hline Coal & 1142.1 & 2509.6 & 2627.2 & 2236.3 & 2316.1 & 2144.2 & 2211.7 \\
\hline केष्ब Oil & 328.2 & 817.6 & 980.2 & 657.2 & 752.5 & 653.7 & 748.5 \\
\hline$\sum$ Gas & 42.2 & 314.8 & 428.4 & 286.5 & 375.9 & 265.4 & 341.7 \\
\hline 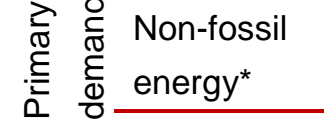 & 110.4 & 407.3 & 771.1 & 427.1 & 875.5 & 440.9 & 889.3 \\
\hline Total & 1622.8 & 4049.4 & 4806.8 & 3607.0 & 4320.0 & 3504.2 & 4191.2 \\
\hline $\begin{array}{l}\mathrm{CO}_{2} \text { emissions } \\
\text { (Mt) }\end{array}$ & 5630 & 15140 & 16200 & 12650 & 13290 & 11520 & 12410 \\
\hline $\begin{array}{l}\text { Primary energy } \\
\text { demand per GDP } \\
\text { (toe/million constant } \\
2000 \$ \text { ) }\end{array}$ & 857.1 & 518.0 & 358.5 & 508.2 & 353.8 & 497.9 & 327.0 \\
\hline $\begin{array}{l}\mathrm{CO}_{2} \text { emissions per } \\
\text { unit of GDP } \\
\left(\mathrm{t}-\mathrm{CO}_{2} / \text { million }\right. \\
\text { constant } 2000 \$)\end{array}$ & 2973.5 & 1945.2 & 1148.3 & 1782.4 & 1036.9 & 1636.7 & 985.4 \\
\hline
\end{tabular}




\begin{tabular}{|ll|ll|ll|ll|}
\hline $\begin{array}{l}\text { The share of } \\
\text { non-fossil energy } \\
(\%)\end{array}$ & 6.8 & 10.1 & 16.0 & 11.8 & 20.3 & 12.6 & 21.2 \\
\hline
\end{tabular}

* Non-fossil energy includes nuclear, hydro, wind, solar and geothermal.

Source: Authors' analysis.

Table 2.3 India's primary energy demand and $\mathrm{CO}_{2}$ emissions by scenario

\begin{tabular}{|c|c|c|c|c|c|c|c|c|}
\hline & & & \multicolumn{2}{|c|}{$\begin{array}{c}\text { Extensive } \\
\text { Economic } \\
\text { Scenario }\end{array}$} & \multicolumn{2}{|c|}{$\begin{array}{c}\text { Reference } \\
\text { Scenario }\end{array}$} & \multicolumn{2}{|c|}{$\begin{array}{l}\text { Enhanced } \\
\text { Low-carbon } \\
\text { Scenario }\end{array}$} \\
\hline & & 2009 & 2020 & 2030 & 2020 & 2030 & 2020 & 2030 \\
\hline \multirow{5}{*}{ 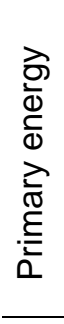 } & Coal & 280 & 489 & 680 & 434 & 544 & 372 & 349 \\
\hline & Oil & 159 & 214 & 312 & 202 & 288 & 196 & 254 \\
\hline & Gas & 49 & 77 & 118 & 82 & 124 & 75 & 122 \\
\hline & $\begin{array}{l}\text { Non-fossil } \\
\text { energy* }\end{array}$ & 181 & 219 & 262 & 228 & 300 & 235 & 353 \\
\hline & Total & 669 & 999 & 1372 & 946 & 1256 & 878 & 1078 \\
\hline \multicolumn{2}{|c|}{$\begin{array}{l}\mathrm{CO}_{2} \text { emissions } \\
\text { (Mt) }\end{array}$} & 1548 & 1523 & 3581 & 2286 & 3004 & 2012 & 2040 \\
\hline
\end{tabular}

* Non-fossil energy includes nuclear, hydro, biomass and waste, and other renewable (wind, solar and geothermal).

Source: IEA (2011b); and authors' analysis.

\section{ASEAN $^{9}$}

ADB (2009) had predicted the future energy demand for ASEAN member countries with the base year of 2005. According to ADB (2009), the ASEAN's total primary energy demand is projected to increase from 492.1 Mtoe in 2005 to 988.2 Mtoe in 2030, growing annually at $2.8 \%$ on average. By energy type, oil will remain the dominant fuel, with an almost constant share of $38.7 \%$ in 2030 , whereas its annual growth rate is expected to be moderate at $2.8 \%$ through 2030. Coal is projected to grow with an average annual rate of $4.8 \%$, which will increase its share from $11.3 \%$ in 2005 to $18.2 \%$ in 2030 . Natural gas will grow moderately, with an average annual growth rate of $2.9 \%$, while its share of total demand is unlikely to change and will stay at around $21 \%$ through 2030. Non-fossil energy will increase from 139.9 Mtoe in 2005 to 212.3 Mtoe in 2030 at an annual growth rate of $1.7 \%$ through 2030 . Among the non-fossil energy sources, hydropower is projected to register the fastest growth rate at $5.2 \%$ per annum, due to the expected development of the vast hydropower potential of the Greater Mekong Subregion (GMS).

The energy efficiency of the whole ASEAN will be improved with the energy intensity decreasing at $1.6 \%$ per annum from 650 toe/million US dollars (constant 2000 US $\$$ ) in 2005 to 432 toe/million dollars in 2030 . The $\mathrm{CO}_{2}$ intensity will decline at a moderate rate of $1.1 \%$ per annum to $908 \mathrm{t}-\mathrm{CO}_{2} /$ million dollars in 2030 (see Table 2.4).

\footnotetext{
${ }^{9}$ This section is based on ADB (2009).
} 
Table 2.4 ASEAN's primary energy demand and $\mathrm{CO}_{2}$ emissions

\begin{tabular}{|c|c|c|c|c|}
\hline & & 2005 & 2015 & 2030 \\
\hline & Coal & 55.7 & 105.5 & 179.6 \\
\hline$\stackrel{\bar{\Phi}}{\varrho} \sum_{\Sigma}^{ \pm}$ & Oil & 192.4 & 230.5 & 382.4 \\
\hline$\geq \overline{0}$ & Gas & 104.1 & 129.8 & 213.9 \\
\hline$\stackrel{\widetilde{\sigma}}{E} \stackrel{\widetilde{\sigma}}{E}$ & Non-fossil energy* & 139.9 & 158.3 & 212.3 \\
\hline$\overline{0}$ & Total & 492.1 & 624.1 & 988.2 \\
\hline $\mathrm{CO}_{2} \mathrm{em}$ & ions (Mt) & 896 & 1243.2 & 2078.9 \\
\hline $\begin{array}{l}\text { Primary } \\
\text { (toe/mil }\end{array}$ & $\begin{array}{l}\text { ergy demand per GDP } \\
\text { constant 2000\$) }\end{array}$ & 650 & 529 & 432 \\
\hline $\begin{array}{l}\mathrm{CO}_{2} \mathrm{em} \\
\left(\mathrm{t}-\mathrm{CO}_{2} / \mathrm{r}\right.\end{array}$ & $\begin{array}{l}\text { ions per unit of GDP } \\
\text { on constant } 2000 \$ \text { ) }\end{array}$ & 1184 & 1054 & 908 \\
\hline
\end{tabular}

* Non-fossil energy includes nuclear, hydro, biomass and waste, and other renewable (wind, solar and geothermal).

Source: ADB (2009); the authors' analysis.

\section{Demand by ASEAN Economies ${ }^{10}$}

Table 2.5 presents ASEAN's primary energy demand, energy intensity and $\mathrm{CO}_{2}$ intensity by country.

\section{Brunei Darussalam}

Primary energy demand is expected to increase at an average annual rate of 3.9\% over the forecast period to reach 6.8 Mtoe in 2030. Oil and natural gas are projected to reach 4.3 Mtoe and 2.5 Mtoe in 2030 with the average annual rate of $6.7 \%$ and $1.3 \%$, respectively. The energy intensity will increase from 394 toe/million dollars (constant 2000\$) to 689 toe/million dollars in 2030.

\section{Cambodia}

Primary energy demand is projected to grow at an average annual rate of $3.7 \%$ through 2030. Coal will register a rapid growth in the second half of the outlook period (2015-2030) at $11.2 \%$ per annum as it will increase to 2.2 Mtoe in 2030 from 0 Mtoe in 2005. Oil is projected to increase from 3.5 Mtoe in 2005 to 4.3 Mtoe in 2030 with an average annual rate of $4.9 \%$. Between 2005 and 2030, hydro is expected to grow at the fastest rate of $19.1 \%$ per annum. The total non-fossil energy will increase from 4.8 Mtoe in 2005 to 5.5 Mtoe in 2030.

\section{Indonesia}

Primary energy demand is expected to increase at an average annual rate of $2.5 \%$ over the forecast period, rising from 176.0 Mtoe in 2005 to 328.4 Mtoe in 2030. Coal, Oil and natural gas are projected to reach $70.1 \mathrm{Mtoe}, 118.1 \mathrm{Mtoe}$ and 53.2 Mtoe with the average annual rate of $2.4 \%, 2.2 \%$ and $4.6 \%$, respectively. Although hydropower and other renewable energy resources, including geothermal power and biofuels, are expected to contribute significantly to

10 The estimates in this section are based on ADB (2009). 
primary energy demand, their absolute role is relatively small in comparison to the growth of primary energy demand from fossil fuels. The economy's projected primary energy mix in 2030 is $21.3 \%$ (coal), $36.0 \%$ (oil), $16.2 \%$ (natural gas), and $26.5 \%$ (non-fossil energy).

\section{Lao People's Democratic Republic}

Primary energy demand is projected to grow at an annual rate of $5.3 \%$ through 2030 . Coal will grow the fastest of all energy sources, increasing to 3.5 Mtoe in 2030 from 0.01 Mtoe in 2005. This growth will be largely due to the construction of a coal power plant that will supply $88.8 \%$ of primary coal demand in 2030 .

\section{Malaysia}

Malaysia's primary energy demand is projected to grow at an average rate of $2.8 \%$ per annum, reaching 130.5 Mtoe in 2030. The share of oil in total primary energy demand is projected to account for $40.1 \%$-- followed by natural gas (36.3\%), coal (17.8\%), and renewable energy (3.8\%). Coal is projected to reach 23.3 Mtoe by 2030 with an average annual growth rate of $5.0 \%$. The increasing presence of coal in primary energy demand is due to the policy on the diversification of power generation whereby coal is scheduled to replace natural gas in the fuel mix. Demand for natural gas is projected to rise modestly over the outlook period at an average rate of $1.8 \%$ per annum to reach 47.4 Mtoe by 2030 . As for oil, its demand is projected to increase to 52.3 Mtoe by 2030 at an average rate of $2.9 \%$ per annum. Growing transport energy demand will be the main driver of the growth in oil demand.

\section{Myanmar}

Myanmar's primary energy demand is projected to grow at an annual rate of $2.6 \%$ from 2005 to 2030 , higher than the growth rate of $2.0 \%$ observed between 1990 and 2005 . Coal will demonstrate the second fastest growth rate of $8.8 \%$. This growth will be driven by industrial demand, particularly by the cement industry, which will be called upon to supply materials for the development of the power infrastructure. The demand for natural gas will have the third fastest growth rate of $5.6 \%$ with oil closely following at $5.2 \%$. The growth in natural gas demand will be caused by the demand for compressed natural gas in the transport sector.

\section{The Philippines}

The Philippines's total primary energy demand is projected to increase from 43.7 Mtoe in 2005 to 79.6 Mtoe in 2030 with an average annual rate of $2.4 \%$. The coal consumption in 2005 was 6.1 Mtoe, about $70 \%$ of which was used in power generation while the rest went into cement production and industry applications. Coal will increase at the rate of $4.5 \%$ per annum to 18.4 Mtoe in 2030 , or $16.1 \%$ of total primary energy demand. Natural gas is projected to increase at $6.5 \%$ per annum from 2.7 Mtoe in 2005 to 12.9 Mtoe in 2030 or $35.1 \%$ of total primary energy demand. Oil is projected to increase at $2.1 \%$ per annum to 24.8 Mtoe in 2030 or $26.1 \%$ of total primary energy demand. The Philippines has plenty of available renewable resources. The total non-fossil energy will grow at $0.6 \%$ per annum to 23.5 Mtoe. The energy intensity will decline from 462 toe/million dollars (constant 2000\$) in 2005 to $296 \mathrm{Mtoe} / \mathrm{million}$ dollars with an average annual rate of $1.8 \%$ decline. 


\section{Singapore}

Singapore's primary energy demand is projected to increase from 30.9 Mtoe in 2005 to 52.6 Mtoe in 2030, an average growth rate of $2.1 \%$ per annum. In 2005, oil accounted for $80.8 \%$ and natural gas $19.2 \%$ of the primary energy consumed. The share of oil is projected to fall to about $66.4 \%$ of total primary energy while the share of gas is projected to rise to $30.8 \%$. Electricity generation accounts for $99.5 \%$ of the total increase in primary gas demand.

\section{Thailand}

Total primary energy demand is projected to grow at an annual rate of 3.0\%, from 100.6 Mtoe in 2005 to 213.0 Mtoe in 2030. Among fossil fuels, coal is projected to grow the fastest at a rate of $4.4 \%$ per annum, followed by natural gas at $3.4 \%$ and oil at $2.3 \%$. The share of coal is projected to increase to $15.7 \%$ in 2030 from $11.4 \%$ in 2005 with most coal being used for the generation of power. The share of gas will also increase from $25.8 \%$ to $28.2 \%$, with most gas used for the generation of power. The share of oil will decline from $45.3 \%$ in 2005 to $37.4 \%$ in 2030 , only because the demand for coal and gas will grow faster. Projected oil demand will be mainly driven by the transport and industry sectors.

\section{Viet Nam}

Primary energy demand is projected to increase from 51.3 Mtoe in 2005 to 131.5 Mtoe in 2030 , increasing at $3.8 \%$ per annum. Among fossil fuels, oil will continue to account for the largest share of total primary energy demand and will be mainly utilized by the transport and industry sectors. The demand for coal and natural gas will be mainly driven by the rapid development of the electricity and industrial sectors, which will account for $21.3 \%$ and $11.4 \%$ of demand, respectively in 2030. Excluding large-scale hydro, and other types of new, clean and renewable energy (such as mini-hydro, wind, biomass, geothermal, and municipal solid waste-landfill) gas will continue to be promoted, contributing to renewable energy's share of $1.3 \%$ of total energy demand in 2030. Nuclear power to be introduced in 2020 is expected to account for $5.9 \%$ of total primary energy demand in 2030 (ADB, 2009).

Table 2.5 ASEAN's primary energy demand, energy intensity and $\mathrm{CO}_{2}$ intensity

\begin{tabular}{|c|c|c|c|c|c|c|c|c|c|}
\hline & \multirow{2}{*}{\multicolumn{3}{|c|}{$\begin{array}{l}\text { Primary energy } \\
\text { demand (Mtoe) }\end{array}$}} & \multicolumn{3}{|c|}{$\begin{array}{l}\text { Primary energy demand per } \\
\text { GDP }\end{array}$} & \multicolumn{3}{|c|}{$\begin{array}{l}\text { Ratio of } \mathrm{CO}_{2} \text { emissions } \\
\text { to GDP (per unit of GDP) }\end{array}$} \\
\hline & & & & $\begin{array}{l}\text { toe/milli } \\
\text { on } \\
\text { constant } \\
2000 \$\end{array}$ & $\begin{array}{r}\text { Chang } \\
200\end{array}$ & $\begin{array}{l}\text { rom the } \\
\text { evel }\end{array}$ & $\begin{array}{l}\text { t-CO2/m } \\
\text { illion } \\
\text { constant } \\
2000 \$\end{array}$ & $\begin{array}{l}\text { Change } \\
\text { the } 2005\end{array}$ & $\begin{array}{l}\text { rom } \\
\text { level }\end{array}$ \\
\hline & 2005 & 2015 & 2030 & 2005 & 2015 & 2030 & 2005 & 2015 & 2030 \\
\hline $\begin{array}{l}\text { Brunei } \\
\text { Darussalam }\end{array}$ & 2.6 & 5.4 & 6.8 & 394 & $77.2 \%$ & $74.9 \%$ & 895 & $56.5 \%$ & $52 \%$ \\
\hline Cambodia & 4.8 & 6.7 & 12.0 & 843 & $-31.0 \%$ & $-52.2 \%$ & 182 & $-3.3 \%$ & $6.6 \%$ \\
\hline Indonesia & 176 & 224.7 & 328.4 & 847 & $-17.1 \%$ & $-34.4 \%$ & 1577 & $-11.9 \%$ & $-26.7 \%$ \\
\hline Lao PDR & 1.9 & 4.9 & 6.9 & 819 & $32.7 \%$ & $-13.7 \%$ & 515 & $563.3 \%$ & $278.8 \%$ \\
\hline Malaysia & 65.9 & 79.6 & 130.5 & 589 & $-19.7 \%$ & $-29.7 \%$ & 1345 & $-9.6 \%$ & $-20.0 \%$ \\
\hline
\end{tabular}




\begin{tabular}{|l|c|c|c|c|c|c|c|l|l|}
\hline Myanmar & 14.3 & 16.7 & 26.9 & 1071 & $-52.8 \%$ & $-76.1 \%$ & 760 & $-35.8 \%$ & $-50.7 \%$ \\
\hline Philippines & 43.7 & 52.9 & 79.6 & 462 & $-20.8 \%$ & $-35.9 \%$ & 780 & $-4.5 \%$ & $-17.4 \%$ \\
\hline Singapore & 30.9 & 38.7 & 52.6 & 275 & $-16.7 \%$ & $-32.7 \%$ & 340 & $-15.9 \%$ & $-26.8 \%$ \\
\hline Thailand & 100.6 & 126.1 & 213.0 & 641 & $-18.1 \%$ & $-30.3 \%$ & 1312 & $-19.1 \%$ & $-32.0 \%$ \\
\hline Viet Nam & 51.3 & 68.6 & 131.5 & 1146 & $-26.9 \%$ & $-42.8 \%$ & 1816 & $-5.9 \%$ & $-14.5 \%$ \\
\hline ASEAN & $\mathbf{4 9 2 . 1}$ & $\mathbf{6 2 4 . 1}$ & $\mathbf{9 8 8 . 2}$ & $\mathbf{6 5 0}$ & $\mathbf{- 1 8 . 6 \%}$ & $\mathbf{- 3 3 . 5 \%}$ & $\mathbf{1 1 8 4}$ & $\mathbf{- 1 1 . 0 \%}$ & $\mathbf{- 2 3 . 3 \%}$ \\
\hline
\end{tabular}

Source: Authors' calculation based on ADB (2009).

\section{3 Impact of environment and climate change policy on energy demand}

Recognizing the serious risks of environmental degradation and climate change, the $\mathrm{ACl}$ economies are giving increasing importance to environmental concerns as the business as usual scenario is no longer an option. The urgency of a global response to climate change has led many $\mathrm{ACl}$ economies to make self-imposed commitments to constrain the growth of their carbon emissions. Table 2.6 summarizes selected $\mathrm{ACl}$ economies' $\mathrm{CO}_{2}$ emission reduction pledges compared pledges by selected advanced Asian economies. However, these targets of emerging $\mathrm{ACl}$ economies are very ambitious. To achieve this high ambitious emission reduction targets, the $\mathrm{ACl}$ needs to take strong efforts and initiatives as well as innovative ideas and policies at the national, regional and global levels both individually and collectively.

Table 2.6 $\mathrm{CO}_{2}$ emissions reduction pledges by selected $\mathrm{ACl}$ and other Asian developed economies

\begin{tabular}{|c|c|c|}
\hline Country & Emission Reduction Target by 2020 and Mitigation Actions & Base \\
\hline PRC & $\begin{array}{l}\text { Endeavor to lower CO2 emission intensity of GDP by } 40 \%-45 \% \text { through an } \\
\text { increase in } \\
\text { The share of non-fossil fuels in primary energy consumption to } 15 \% \\
\text { Forest coverage by } 40 \text { million hectares } \\
\text { Forest stock volume by } 1.3 \text { billion m3 }\end{array}$ & 2005 \\
\hline India & $\begin{array}{l}\text { Endeavor to reduce the emission intensity of GDP by } 20 \%-25 \% \text {, excluding } \\
\text { agriculture, through } \\
\text { Increasing the fraction of electricity derived from wind, solar, and small hydro } \\
\text { to } 20 \% \text { in } 2020 \text { (from } 8 \% \text { in } 2005 \text { ) } \\
\text { Adopting building energy codes by } 2012 \\
\text { Adopting fuel efficiency standards by } 2011 \\
\text { Increasing forest cover to sequester } 10 \% \text { of annual emissions }\end{array}$ & 2005 \\
\hline Indonesia & $\begin{array}{l}\text { Achieve } 26 \% \text { reduction through } \\
\text { Sustainable peat land management } \\
\text { Reducing deforestation and land degradation } \\
\text { Carbon sequestration projects in forestry and agriculture }\end{array}$ & BAU \\
\hline
\end{tabular}




\begin{tabular}{|l|l|l|}
\hline & \multicolumn{1}{|c|}{ Promoting energy efficiency, renewable energy, and low-carbon transport } & \\
\hline Japan & $\begin{array}{l}\text { Achieve 25\% reduction, based on the assumption of a fair and effective } \\
\text { international framework with the participation of all major economies agreeing to } \\
\text { the set targets.. }\end{array}$ & 1990 \\
\hline $\begin{array}{l}\text { Republic } \\
\text { of Korea }\end{array}$ & $\begin{array}{l}\text { Achieve } 30 \% \text { reduction below projected levels by 2020, which equates to } \\
\text { approximately 4\% below } 2005 \text { levels }\end{array}$ & BAU \\
\hline Malaysia & Achieve $40 \%$ reduction below 2005 levels by 2020 & BAU \\
\hline Singapore & Achieve $16 \%$ reduction through legally-binding global agreement & BAU \\
\hline Thailand & Achieve $30 \%$ reduction below BAU & BAU \\
\hline
\end{tabular}

$\mathrm{CO}_{2}=$ carbon dioxide; PRC = People's Republic of China; GDP = gross domestic product; $\mathrm{m}^{3}=$ cubic meter; US = United States; BAU= Business as usual.

Sources: UNFCCC (2010a); UNFCC (2010b); Korea: Korea Energy Management Corporation (2010);

Singapore: Ministry of Environment and Water Resources (MEWR), Singapore (2010).

\section{People Republic of China}

The PRC pledges to reduce the intensity of carbon dioxide emissions per unit of GDP by $40 \%$ to $45 \%$ in 2020 compared to the 2005 level. PRC will take the following specific measures: (i) intensify effort to conserve energy and improve energy efficiency; (ii) vigorously develop renewable energy and nuclear energy and increase the share of non-fossil fuels in primary energy consumption to around $15 \%$ by 2020 ; (iii) increase forest carbon sinks by enhancing forest coverage by 40 million hectares and forest stock volume by 1.3 billion cubic metres by 2020 compared to the 2005 level; (iv) step up efforts to develop a green economy, low-carbon economy and circular economy; and (v) enhance research, development and dissemination of climate-friendly technologies.

As part of the 11th Five Year Plan (2006-2010), the PRC previously adopted an overall energy efficiency goal of reducing energy consumption per unit of GDP by $20 \%$ in 2010 compared to the level of year 2005. In order to accomplish this goal, PRC has deployed a series of policy, legal and economic measures.

The prediction results generated from the CGE model is used to analyze the impact of the Enhanced Low-carbon Economic Scenario on PRC's future energy demand. Figure 2.1 shows both the primary energy demand and mix in those three scenarios. The Extensive Economic Scenario depicts that economy will continue to rely on heavy industries and make little progress on energy efficiency. Under this case, the total energy consumption will be 4806.8 Mtoe in 2030, which has increased by $196.2 \%$ to that of 2005. And the proportions of coal, oil, natural gas, and non-fossil energy are $54.7 \%, 20.4 \%, 8.9 \%$, and $16.0 \%$, respectively. In the Reference Scenario, the Chinese government will achieve the low end of national abatement pledge that $\mathrm{CO}_{2}$ intensity will be reduced by $40 \%$ in 2020 compared with 2005 . Under this case, PRC's total primary energy demand is projected to reach 4320.0 Mtoe in 2030, reduced by $10.1 \%$ compared to that of the Extensive Economic Scenario. The share of non-fossil energy in total primary energy demand will increase to $20.3 \%$ in 2030. 
Figure 2.1 PRC's primary energy demand in 2030 by scenario

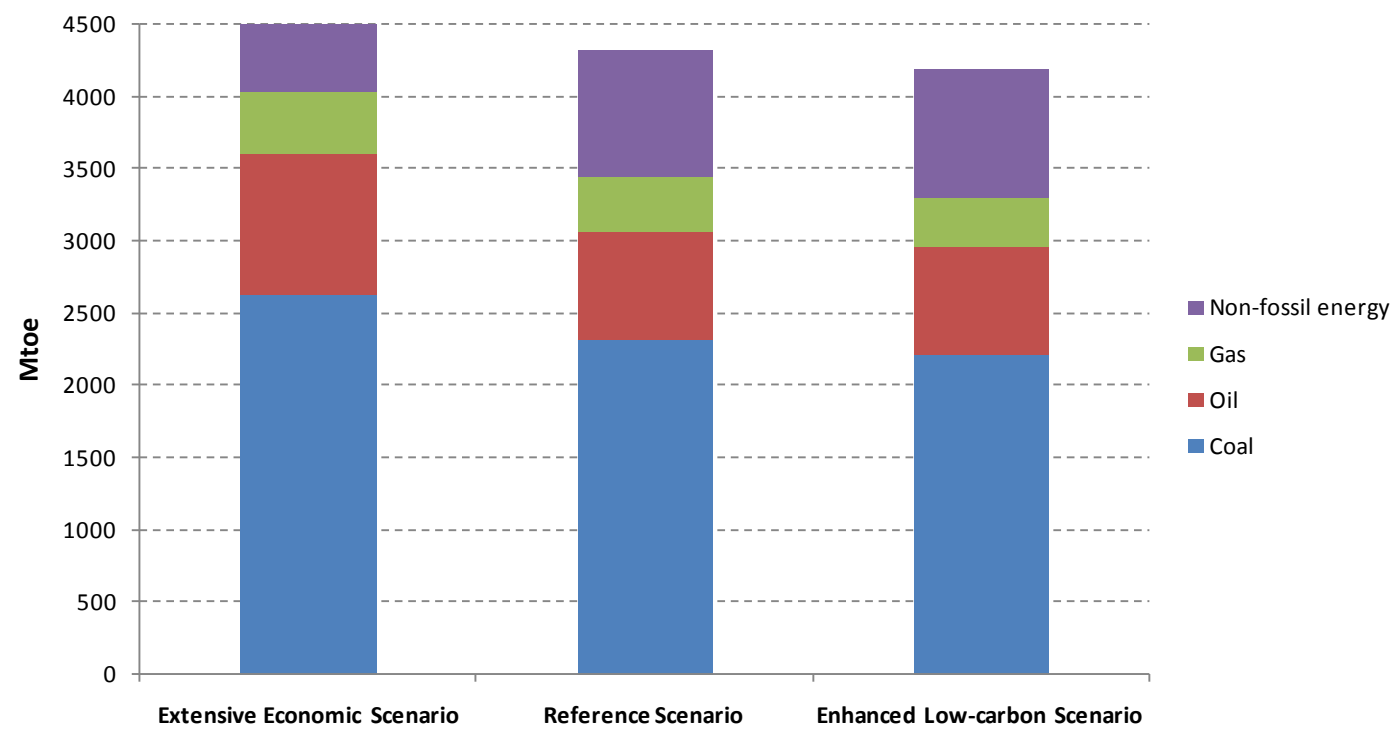

Source: Authors' calculation

If more polices for achieving low carbon level such as carbon taxes can be introduced in PRC in the future, total energy demand will increase at a moderate growth with rapid development of the non-fossil energy. This case is depicted in the Enhanced Low-carbon Economic Scenario. Primary energy demand will reach 4191.2 Mtoe in 2030, reduced by $3.0 \%$ compared to that of the Reference Scenario as well as by $12.8 \%$ compared to the Extensive Economic Scenario. Coal, oil and natural gas will account for $52.8 \%, 17.9 \%$ and $8.2 \%$ respectively. The non-fossil energy will grow at a high annual rate of $8.7 \%$ to 889.3 Mtoe, accounting for $21.2 \%$ of total primary energy demand in 2030 .

\section{India}

India has announced that it will reduce its emission intensity by $20 \% \sim 25 \%$ in 2020 compared to the 2005 level. To achieve this target, India has outlined a five-step plan of actions: (i) mandatory fuel efficiency standards for all vehicles by December 2011; (ii) a building code that encouraged energy conservation, with a recommendation to local governments to make this mandatory; (iii) amendments to various laws to reduce energy intensity of industrial activities; (iv) regular monitoring of the state of the forests, which now absorbed about 10 percent of India's greenhouse gas emissions; and (iv) half of the new coal based power plants coming up to use new clean coal technologies ---- super critical, ultra super critical and coal gasification. 
Figure 2.2 India's primary energy demand in 2030 by scenario

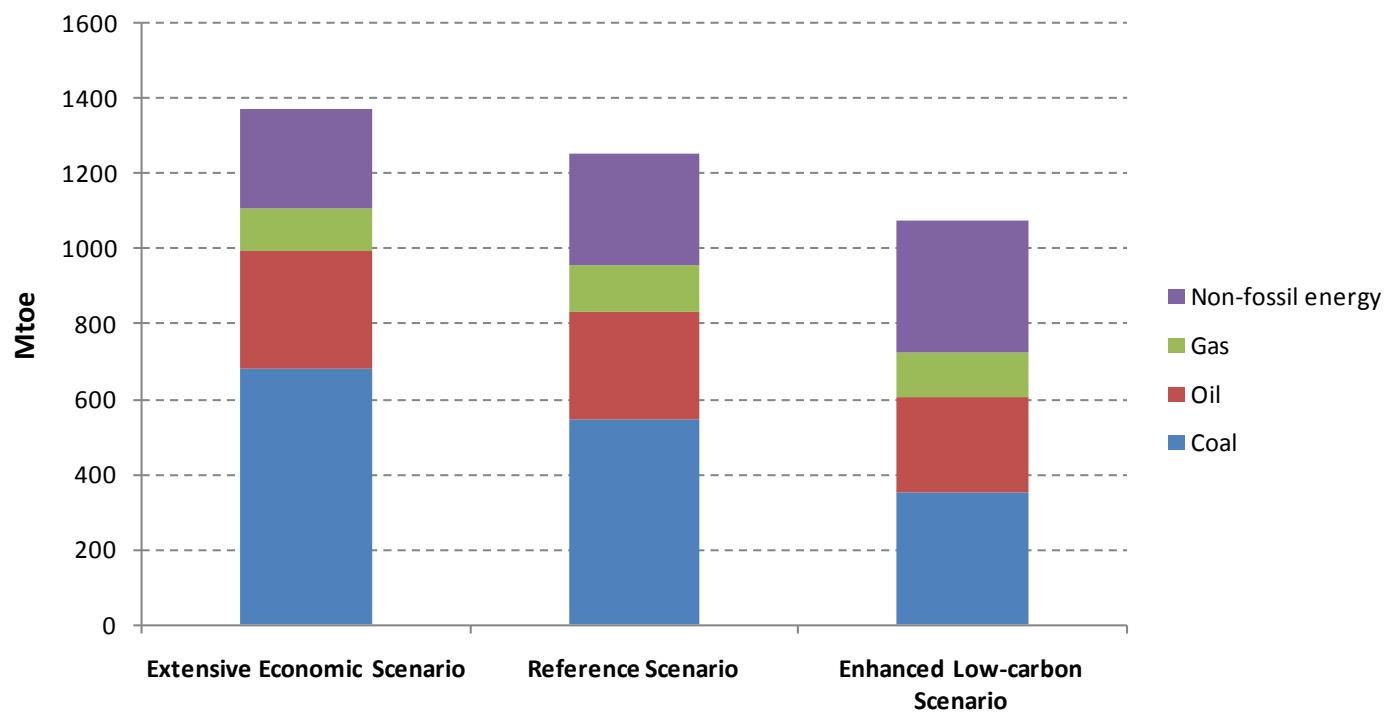

Source: IEA (2011b); the authors' calculation

India's abatement pledge and actions will reduce total energy demand and the share of coal, as well as promote the development of the non-fossil energy. Figure 2.2 shows both primary energy demand and portfolio by scenario. In the Extensive Economic Scenario, primary energy demand will reach 1372 Mtoe in 2030 and the proportions of coal, oil, natural gas and non-fossil energy are $49.6 \%, 22.7 \%, 8.6 \%$ and $19.1 \%$ respectively. The total energy demand in the Reference Scenario is projected to be 1256 Mtoe in 2030, reduced by $8.5 \%$ compared to that of the Extensive Economic Scenario, and the proportions of coal, oil, natural gas and the non-fossil energy will be $43.3 \%, 22.9 \%, 9.9 \%$ and $23.9 \%$ respectively. Primary energy demand in the Enhanced Low-carbon Economic Scenario is projected to be 1078 Mtoe, reduced by $142 \%$ compared to that of the Reference Scenario as well as by $21.4 \%$ compared to that of the Extensive Economic Scenario. The share of coal will further be reduced to $32.4 \%$ while the share of the non-fossil energy will increase to $32.8 \%$ in 2030.

\section{ASEAN}

In the ASEAN Plan of Action for Energy Cooperation (APAEC) 2010-2015, all member countries have agreed to reduce regional energy intensity of at least $8 \%$ by 2015 based on the 2005 level and to achieve a collective target of $15 \%$ of renewable energy in the total regional power installed capacity by 2015. In addition, most ASEAN countries have own abatement action pledges which have been collected by the Asia Pacific Energy Research Center (APERC, 2010).

Brunei Darussalam pledged to contribute to the $25 \%$ regional improvement in energy intensity by 2030 compared to the 2005 level, as agreed by APEC (Asia Pacific Economic Co-operation ) Leaders in the 2007 Sydney Declaration.

Indonesia had made two separate pledges: (1) reduce greenhouse gas emissions $26 \%$ below the business-as-usual scenario; and (2) reduce emissions by as much as $41 \%$ below 
business-as-usual, contingent on the provision of international support. Indonesia has also set an overall energy efficiency goal of achieving an energy elasticity of GDP of less than 1.0 from 2005 to 2025 , while realizing an energy saving potential of as much as $41 \%$ compared to business-as-usual.

Malaysia pledged to reduce carbon dioxide emissions per unit of GDP in 2020 by up to $40 \%$ relative to the 2005 level contingent on the provision of international finances. Malaysia is in the process of instituting a renewable energy law and one of the mechanisms of the said law is feed-in tariffs to promote the use of renewable energy. Malaysia also plans to include nuclear energy in the electricity generation fuel mix after 2020 .

The Philippines had set the goal of improving energy utilization through the National Energy Efficiency and Conservation Program (NEECP) launched in August 2004. The government estimates that this program will save a cumulative 9.08 million barrels of fuel oil equivalent during the period 2007-2014 compared with business-as-usual scenario. Sector energy efficiency goals are to reduce final energy demand by $10 \%$ (under the 2009-2030 Philippine's Energy Plan) in each sector: industry, residential, commercial, transport, and agriculture.

Singapore pledged to reduce greenhouse gas emissions to $16 \%$ below the business-as-usual scenario by 2020 . Singapore has also set an overall energy efficiency goal of reducing energy intensity of GDP by $20 \%$ by 2020 and $35 \%$ by 2030 compared with the level of 2005.

Thailand pledged to reduce energy intensity by $8 \%$ by 2015 and $25 \%$ by 2030 compared with the level of 2005. To reduce greenhouse gas emissions, Thailand will also increase the use of renewable energy and nuclear power.

Viet Nam pledged to reduce total energy consumption by $5 \%$ to $8 \%$ by 2015 compared with the level of 2006. The government had also approved the following targets for renewable energy and the development of nuclear power plants: (i) achieve a 5\% share of renewable energy in total commercial primary energy by 2025 and $11 \%$ by 2050; (ii) introduce the first nuclear power plant in 2020 which will increase the contribution of nuclear energy to the energy mix.

For quantitative analysis of the impact of climate policies on ASEAN's energy demand, the prediction results from IEA (2009) are referred in this section. IEA (2009) provided two scenarios----the Reference Scenario and the 450 Scenario----with the base year of 2007. The Reference Scenario takes into account the current energy policies without consideration of future abatement actions. The 450 Scenario describes the implications for energy markets of a coordinated global effort to achieve a trajectory of greenhouse gas emissions that would ensure the stabilization of the concentration of those gases in the atmosphere at $450 \mathrm{ppm}$ $\mathrm{CO}_{2}$-eqivalent.

Figure 2.3 shows the prediction results for ASEAN's primary energy demand in 2030 from 
ADB (2009) and IEA (2009). According to ADB (2009), ASEAN's primary energy demand will be 988.2 Mtoe in 2030 and the proportions of coal, oil, natural gas and the non-fossil energy will be $18.2 \%, 38.7 \%, 21.6 \%$ and $21.5 \%$ respectively. In the Reference Scenario of IEA (2009), ASEAN's primary energy demand will be 903 Mtoe in 2030 and the proportions of coal, oil, natural gas and the non-fossil energy will be $24.3 \%, 29.5 \%, 22.0 \%$ and $24.0 \%$ respectively. In the 450 Scenario of IEA (2009), ASEAN's primary energy demand will be $824 \mathrm{Mtoe}$, reduced by $8.7 \%$ compared to that of the Reference Scenario, and the proportions of coal, oil, natural gas and the non-fossil energy will become $18.2 \%, 27.2 \%, 18.4 \%$ and $36.2 \%$ respectively.

Figure 2.3 ASEAN's primary energy demand in $\mathbf{2 0 3 0}$ by report and scenario

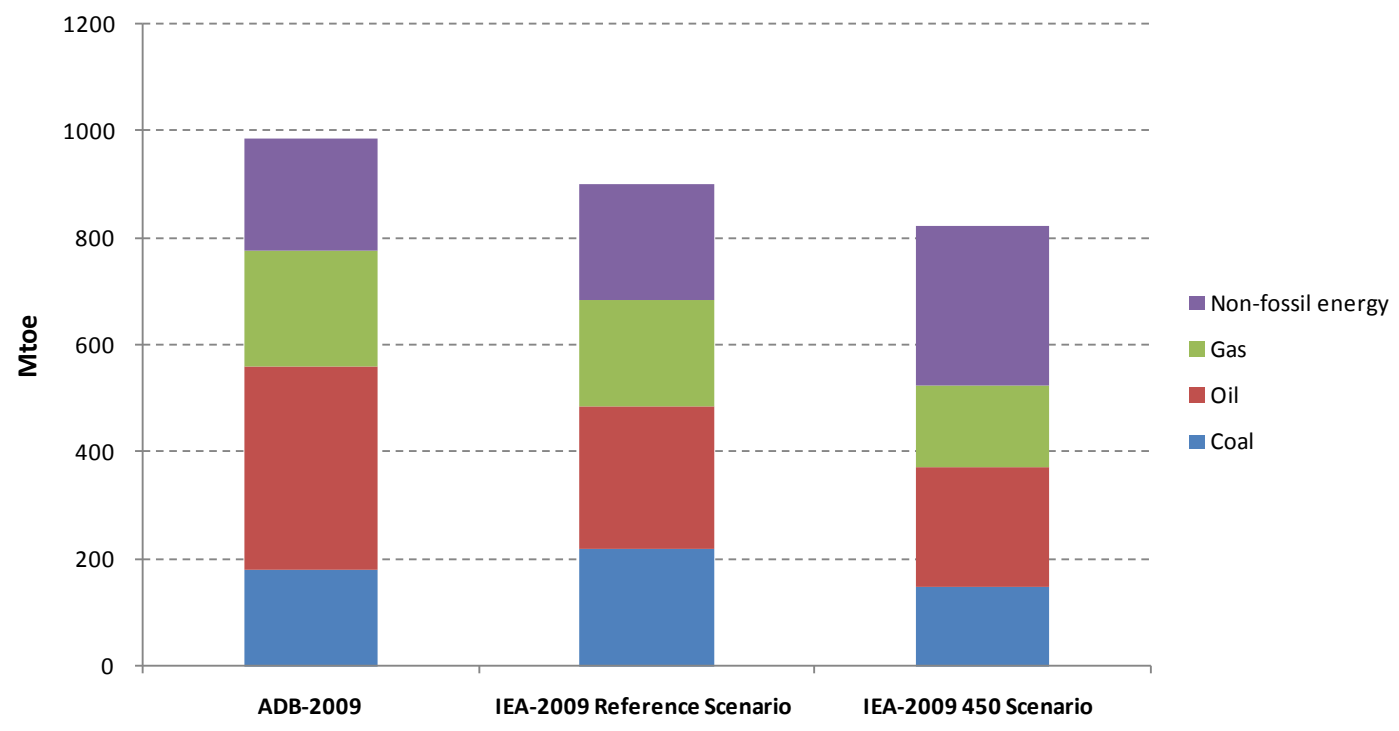

Source: ADB (2009), IEA (2009); and authors' calculation.

\section{3. $\mathrm{ACl}$ energy security evaluation}

\subsection{Potential energy supply in $\mathrm{ACI}^{11}$}

The ACl plays a key role in Asia's energy supply. In 2008, ACl's primary energy production accounted for $95.4 \%$ of Asia, of which coal, oil and gas production respectively accounted for 98.7\%, 97.6\% and 86.6\% (IEA, 2011a).

\section{People Republic of China}

To meet the growing power and industrial demand, PRC's coal production is expected to continue to grow at a rapid rate. In the 11th Five-Year Plan, PRC's coal production in 2015 and 2030 will reach 1552.0 Mtoe and 1820.0 Mtoe respectively. Net coal imports will increase to 406.7 Mtoe in 2015 and 496.1 Mtoe in 2030. Oil production before 2030 is relatively stable, which is expected to increase slightly in 2015, but to decrease thereafter. PRC's oil production in 2015 and 2030 will reach 195.0 Mtoe and 190.0 Mtoe, respectively. Due to immense increase in oil demands and decline in production, PRC's net oil imports will arrive at 370.6 Mtoe in 2015 and 562.5 Mtoe in 2030. Because of potential development prospects of coaled methane gas and other non-traditional sources, gas production is expected to continue to grow

\footnotetext{
${ }^{11}$ Data in this section is from APERC (2009) except specified.
} 
at a rapid rate in the future. Gas production in 2015 and 2030 will reach 93.6 Mtoe and 103.5 Mtoe, respectively. Net gas imports will increase rapidly to reach 107.7 Mtoe in 2015 and 272,4 Mtoe in 2030.

\section{India}

India's production of energy is projected to rise in response to strong domestic demand. Coal production in 2015 and 2030 will reach 255 Mtoe and 323 Mtoe, respectively. The net coal imports will reach 72 Mtoe in 2015 and 155 Mtoe in 2030 (IEA, 2011a). Oil production in 2015 and 2030 will reach $45 \mathrm{Mtoe}(0.9 \mathrm{mb} / \mathrm{d})$ and $40 \mathrm{Mtoe}(0.8 \mathrm{mb} / \mathrm{d})$, respectively. The net oil imports will grow rapidly due to its tremendous growth in oil demand, and net oil imports will reach 133 Mtoe and 258 Mtoe in 2015 and 2030, respectively. Gas production in 2015 and 2030 will reach 54 Mtoe $(60 \mathrm{bcm})$ and 83 Mtoe $(92 \mathrm{bcm})$, respectively. India's gas imports will increase rapidly and reach 13 Mtoe in 2015 and 38 Mtoe in 2030.

\section{ASEAN}

ASEAN may turn into a net energy importer at 125.4 Mtoe in 2030-changing from a net energy exporter at 79.5 Mtoe in 2005. It is projected to maintain a net export position until 2025 or so. However, by 2030 ASEAN as a whole is expected to become a net importer of gas. Its growing oil demand will be increasingly met by imports given the decline in production from the current major producers such as Indonesia, Malaysia, Thailand, and Viet Nam (APERC and ADB, 2009).

Indonesia's coal production is expected to continue growing in the future to satisfy domestic and export demand, as mining companies move to exploit reserves further inland. Coal production in 2015 and 2030 will reach 208.4 Mtoe and 288.5 Mtoe, respectively. Net coal imports will increase and reach 161.1 Mtoe in 2015 and 215.3 Mtoe in 2030. As the oil fields mature, oil production will decrease from 52.4 Mtoe $(1.05 \mathrm{mb} / \mathrm{d})$ in 2005 to 48.8 Mtoe $(0.98 \mathrm{mb} / \mathrm{d})$ in 2030 — with increased net oil imports reaching 18.8 Mtoe in 2015 and 71.1 Mtoe in 2030. Gas production will continue to grow at a rapid rate-reaching 65.2 Mtoe in 2015 and 66.2 Mtoe in 2030. Net gas exports will decrease due to its growth in domestic demand and reach 28.0 Mtoe in 2015 and 15.3 Mtoe in 2030.

Malaysia's coal production will continue to grow, but future production and supply gap will continue to increase due to its limited reserves. Coal production in 2030 will reach 1.0 Mtoe and net coal imports will reach 13.5 Mtoe in 2015 and 22.3 Mtoe in 2030. Similar to Indonesia, Malaysia also faces gradual depletion of oil resources; the country's oil production is expected to initially increase but decline thereafter. Oil production in 2015 and 2030 will reach 40 Mtoe and 30.1 Mtoe, respectively. Net oil exports will decrease and reach 7.7 Mtoe in 2015. Net oil imports will reach at 23.4 Mtoe in 2030. Malaysia's gas production will continue to grow. Gas production will reach 56.3 Mtoe in 2015 and 75.0 Mtoe in 2030. Net gas exports will become 27.4 Mtoe in 2015 and 27.6 Mtoe in 2030.

Because of the limited domestic resources, oil and gas in the Philippines is predicted to be depleted in 2030. The oil production will reach 0.8 Mtoe and 0.5 Mtoe as well as gas production will reach 3.6 Mtoe and 1.1 Mtoe in 2015 and 2030, respectively. As a result, net oil and gas imports are expected to increase. Oil net imports will become 19.2 Mtoe and 26.4 
Mtoe while gas at 2.0 Mtoe and 11.8 Mtoe in 2015 and 2030, respectively. Net coal imports will increase greatly and reach 8.2 Mtoe in 2015 and 13.6 Mtoe in 2030.

Subject to the lack of resources and with its growing energy demand, Singapore's net imports of oil and gas will continuously increase. Net oil imports will reach 28.4 Mtoe and 35.2 Mtoe and net gas imports at 9.4 Mtoe and 16.2 Mtoe in 2015 and 2030, respectively.

Thailand's coal and gas production will first reach its peak, but decline thereafter, while oil production will continue to decrease. Coal production in 2015 and 2030 will reach 7 Mtoe and 6 Mtoe, respectively, resulting in a large increase in net coal imports. Net coal imports will reach 9.6 Mtoe in 2015 and 27.4 Mtoe in 2030. Oil production will reach 6 Mtoe and 6 Mtoe and gas production will reach 20 Mtoe and 16.5 Mtoe in 2015 and 2030, respectively. Net oil imports will reach 49.3 Mtoe and 81.1 Mtoe, while gas net imports are seen to increase to 14.4 Mtoe and 43.6 Mtoe in 2015 and 2030, respectively.

Viet Nam's coal production will continue to grow but its oil production is expected to show a downward trend as oil reserves decline. Coal production will reach 28.3 Mtoe in 2015 and 38.6 Mtoe in 2030. Oil production in 2015 and 2030 will reach 16.2 Mtoe and 15.7 Mtoe, respectively. Vietnam will turn into a net oil importer and net oil imports will reach 6.6 Mtoe in 2015 and 40.4 Mtoe in 2030. Gas production in 2015 and 2030 will reach 10.2 Mtoe and 14.8 Mtoe, respectively. Due to the rapid development of electric power and industrial sectors, Net exports of coal will initially increase but later on decrease while its net gas exports will continue to decrease until the country becomes a net importer. Net exports of coal in 2015 and 2030 will reach 14.7 Mtoe and 10.6 Mtoe, respectively. Net gas exports in 2015 will reach 1.6 Mtoe and net gas imports in 2030 will be around 0.2 Mtoe.

Brunei's oil and gas production is predicted to remain at the current level. Oil production in 2015 and 2030 will reach 11.17 Mtoe and 9.61 Mtoe, while gas production will reach 10.1Mtoe and 8.68 Mtoe, respectively. However, due to growth in domestic demand, net exports are seen to decrease. Brunei's net oil exports will reach 8.4 Mtoe and 5.3 Mtoe, while gas net exports are expected to reach 7.6 Mtoe and 6.2 Mtoe in 2015 and 2030, respectively.

\subsection{Energy import and export ${ }^{12}$}

\section{People Republic of China}

The PRC changed from being a net energy exporter into a net energy importer in 1997. Since 2002, the amount of energy import of the country had increased dramatically, reaching 254 Mtoe in 2008. The PRC had always been a coal exporter, and it reached its coal export climax in 2001 and 2004. In recent years, the country's net coal export had been decreasing substantially. In 2008, it only registered at 7.7 Mtoe and the net coal import exceeded 50 Mtoe, making the PRC one of the large coal importer in the world. Meanwhile, in terms of oil, PRC became a net oil importer in 1993, and became the second largest oil importer in the world in 2009-with 253.3 Mtoe of oil imports and 34.1 Mtoe of exports resulting in 219.2 Mtoe of net imports. In 2009, Saudi Arabia and Angola were PRC's two largest sources of oil imports, together accounting for over one-third of PRC's total imported crude oil payments. Since 2007, PRC has become a net gas importer. In 2009, gas imports were 7.63 billion cubic meters.

\footnotetext{
${ }^{12}$ Except specified, import and export data in 2008 are all from EDMC (2011), while data in 2009 are from BP (2010). In addition, Indian import and export data are from IEA (2011).
} 
Nearly two-third of gas imports came from Australia. Other important sources are Malaysia and Indonesia, which provide $11.5 \%$ and $9.4 \%$ of the total gas imports (see Figure 3.1 )

\section{India}

India has always been a net oil importer, and its oil imports have increased significantly since 1987, reaching 156.2 Mtoe or about $70 \%$ of its oil needs in 2009- the sixth largest net importer of oil in the world. The Middle East, particularly Saudi Arabia, Iran and Kuwait, are India's most important sources of oil imports. However, it is worth mentioning that India was the largest exporter of petroleum products among the $\mathrm{ACl}$ countries. It exported $38.4 \mathrm{Mtoe}$ of petroleum products in 2008 (IEA, 2011a). India had transformed into a net coal importer since the late 1980s, and its net coal imports increased rapidly in recent years, registering 36 Mtoe in 2008. The coal that is being used in India's power sector is imported mainly from Indonesia (Coal Network, 2010). Net gas imports have increased significantly since 2003, and reached about 9 Mtoe in 2008. According to BP (2010), the total gas imported in 2009 was 12.62 billion cubic metres. Qatar is the largest source of gas imports, accounting for about two-thirds of the total natural gas imports. From the $\mathrm{ACl}$ countries, India imported 0.08 billion cubic metres and 0.25 billion cubic metres of natural gas from Indonesia and Malaysia in 2009, respectively. The landmark deal on Iran's nuclear program will improve the energy connectivity of India with West Asia and hence the energy security of India.

\section{ASEAN}

According to IEA (2011a), the total net energy imports of the ASEAN reached 205 Mtoe in 2008, of which net imports of crude oil and petroleum products were 257 Mtoe and 16.5 Mtoe, respectively while net exports of coal and natural gas were 36.5 Mtoe and 32 Mtoe, respectively. Almost all natural gas exports and most of the coal exports went to countries inside Asia while the vast majority of imported oil came from the Middle East. The ASEAN is an important exporter of liquefied natural gas (LNG) to world markets. In mid-2009, it had 31\% of global LNG production capacity - 978 Mtoe per year.

Indonesia is the world's leading steam coal exporter and the third-largest LNG exporter. The net energy exports of Indonesia have risen in recent years with 115 Mtoe in 2008. The amount of Indonesia's net coal imports and exports had increased rapidly since the 1990s, reaching 94 Mtoe in 2008. The main markets of Indonesian coal are Japan, Taiwan;China, Korea, the Philippines, PRC, and OECD countries of Europe. Meanwhile, Indonesia used to be a net oil exporter, but since 1996, the country's s oil exports have started to decline, and Indonesia became a net oil importer in 2004. In recent years, oil imports of Indonesia remained stable, reaching 12.8 Mtoe in 2008. In terms of natural gas, Indonesia has been a major exporter, with net exports showing an increasing trend in recent years. In 2008, the net exports of natural gas by Indonesia reached 33.9 Mtoe and this increased further to 35.67 Mtoe in 2009 (BP, 2010). 
Figure 3.1 Change of PRC's oil imports, 1993-2008

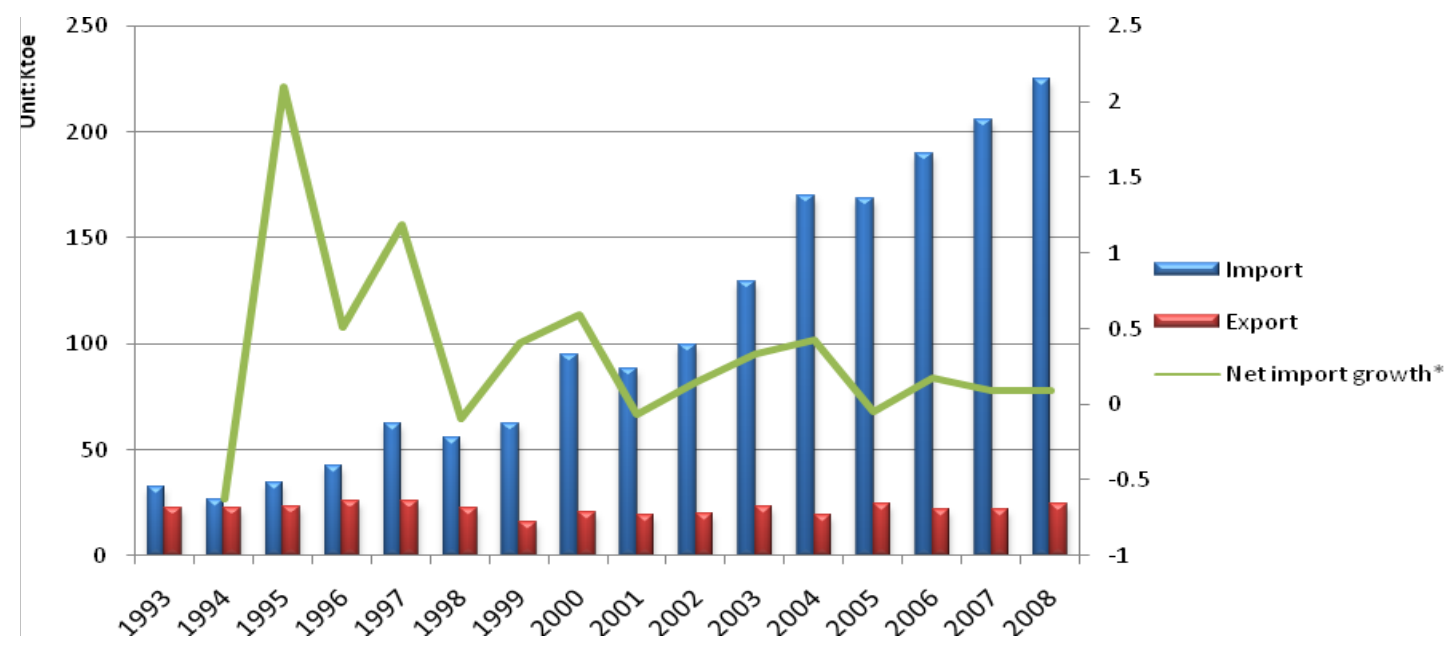

*Net import growth=(net imports of this year- net imports of last year)/ net imports of last year.

Source: Authors' calculation

Indonesia currently exports LNG to Japan, South Korea, Taiwan;China and PRC, while piped gas are being shipped to Singapore and Malaysia.

Malaysia is the world's second-largest exporter of LNG. The net energy exports were recorded at 17.6 Mtoe in 2008. Currently, $94 \%$ of the coal that is being used in Malaysia is imported due to the high extraction cost of locally sourced coal. The net coal imports of Malaysia had increased rapidly since 2000, reaching 8.1 Mtoe in 2008, mostly from Australia, PRC, South Africa and Indonesia. Malaysia is a net oil exporter, with net exports reaching its climax at 18.7 Mtoe in 1989, thereafter net oil exports of Malaysia have been declining since 1989, settling at 8.6 Mtoe in 2008. Malaysia has always been a net exporter of natural gas, and the peak was achieved in 2005 at 25.6 Mtoe. Thereafter, the net exports of natural gas by Malaysia decreased rapidly that in 2008, reaching only 17.2 Mtoe. Meanwhile, Malaysia exported just under 31 billion cubic metres of LNG, mostly to Japan, Korea and Taiwan;China in 2008.

Vietnam exports several forms of energy among ASEAN countries, as it exports oil, coal and natural gas. Its energy export reached 10.6 Mtoe in 2008. The net coal exports had increased rapidly since 2001, but these decreased from 17.5 Mtoe in 2007 to 10.5 Mtoe in 2008. Vietnam transformed to a net oil exporter in 1991, reaching the peak of 10.2 Mtoe in 2004, thereafter deckling rapidly, settling at 0.3 Mtoe in 2008. The net export of natural gas also showed a rapidly decreasing trend in recent years, reaching 0.2 Mtoe 2008.

Brunei exports large quantities of oil and natural gas and it is ninth-largest LNG exporter in the world. Recently, the oil export of Brunei decreased, reaching 8.4 Mtoe in 2008 as well as natural gas export. Most of Brunei's oil exports are shipped to Australia, Japan, Korea, Thailand, Indonesia and India, and most of its gas is exported, in the form of LNG, to Japan and South Korea.

Singapore is the largest energy importer among ASEAN countries, importing oil and natural gas. Its net energy imports maintained a steady growth, and reached 59.6 Mtoe in 2008. Net oil imports continued to grow in recent years reaching 53.4 Mtoe in 2008. Singapore mainly 
imports crude oil from the Middle East and the Asia-Pacific and export refined petroleum products to many countries. Net imports of natural gas have grown rapidly since 2000 reaching 6.2 Mtoe in 2008. Four offshore gas pipelines supply Singapore's gas needs.

Currently Thailand is one of ASEAN's largest oil importers. Its net energy imports reached 48.2 Mtoe in 2008. The net coal imports maintained a growing trend since 1998, reaching 10.1 Mtoe in 2008. Net oil imports have decreased in recent years reaching 29.7 Mtoe in 2008. Most crude oil imports came from countries in the Middle East, including the United Arab Emirates, Saudi Arabia, Oman, Qatar and Yemen. The net imports of natural gas had been increasing to reach 8.3 Mtoe in 2008.

The Philippines has also been relying on oil and coal imports to meet its energy demand. Net energy imports reached 16.7 Mtoe in 2008. Net coal imports have remained stable in recent years reaching 4.8 Mtoe in 2008. Net oil imports reached its peak in 1998 at 18.1 Mtoe, thereafter it had been decreasing to reach 1.2 Mtoe in 2008. Philippine has been self-sufficient for its natural gas demand.

\subsection{Energy security evaluation}

The energy security evaluation consists of the evaluation of (i) energy self-sufficiency; (ii) dependence on imported energy; (iii) oil import diversification; (iv) transport security; and (v) energy infrastructure. These will be discussed in the following subsections in details. Tables 3.1 and 3.2 present energy security evaluation and energy security forecast of $\mathrm{ACl}$.

\subsubsection{Energy self-sufficiency ${ }^{13}$}

Energy self-sufficiency is defined to be the ratio of domestic energy production to total energy consumption. Figure 3.2 presents the trends in self-sufficiency in major $\mathrm{ACl}$ economies. Prior to 1997, PRC's was basically self-sufficient to meet its energy demand. Subsequently, with the rapid growth in energy demand, energy self-sufficiency began to decline. PRC's energy self-sufficiency in 2008 was $93.1 \%$. India's energy demand has relied on imports for a long time. In mid-1980s, energy self-sufficiency had improved. But since 1990s, India's energy self-sufficiency continued to decline reaching $75.4 \%$ in 2008 . Energy self-sufficiency among ASEAN countries varies considerably. Brunei has the highest energy self-sufficiency in ASEAN as it always relies on domestic production to meet energy needs and it energy exports are large. In 2008, Brunei's energy self-sufficiency was 586.3\%.

Energy exports of Indonesia, Malaysia and Vietnam have been large, but their energy self-sufficiencies have been decreasing. From 1984 to 2008, the respective energy self-sufficiency decreased from $344.3 \%$ to $156.3 \%$ for Indonesia; from $243.9 \%$ to $123.6 \%$ for Malaysia; from $1737.7 \%$ in 2000 to $123.3 \%$ in 2008 for Viet Nam. To meet the energy demand, Singapore, Philippines and Thailand have been relying on imports with the self-sufficiency of $0.5 \%, 59.2 \%$ and of $56.2 \%$ respectively in 2008

Based on energy demand forecast and supply estimates, energy self-sufficiencies in the $\mathrm{ACl}$ countries are presented in Table 3.2. Energy self-sufficiency in most countries is expected to decline through 2030. Among the $\mathrm{ACl}$ countries, by 2030, energy self-sufficiency will decline to $62.7 \%$ for PRC; and less than 50\% for India; while for ASEAN countries, only Brunei is expected to remain fully energy self-sufficient.

\footnotetext{
13 Data are taken from EDMC (2011) and IEA (2011).
} 
Figure 3.2 change of self-sufficiency in $\mathrm{ACl}, \mathbf{2 0 0 0 - 2 0 0 8}$

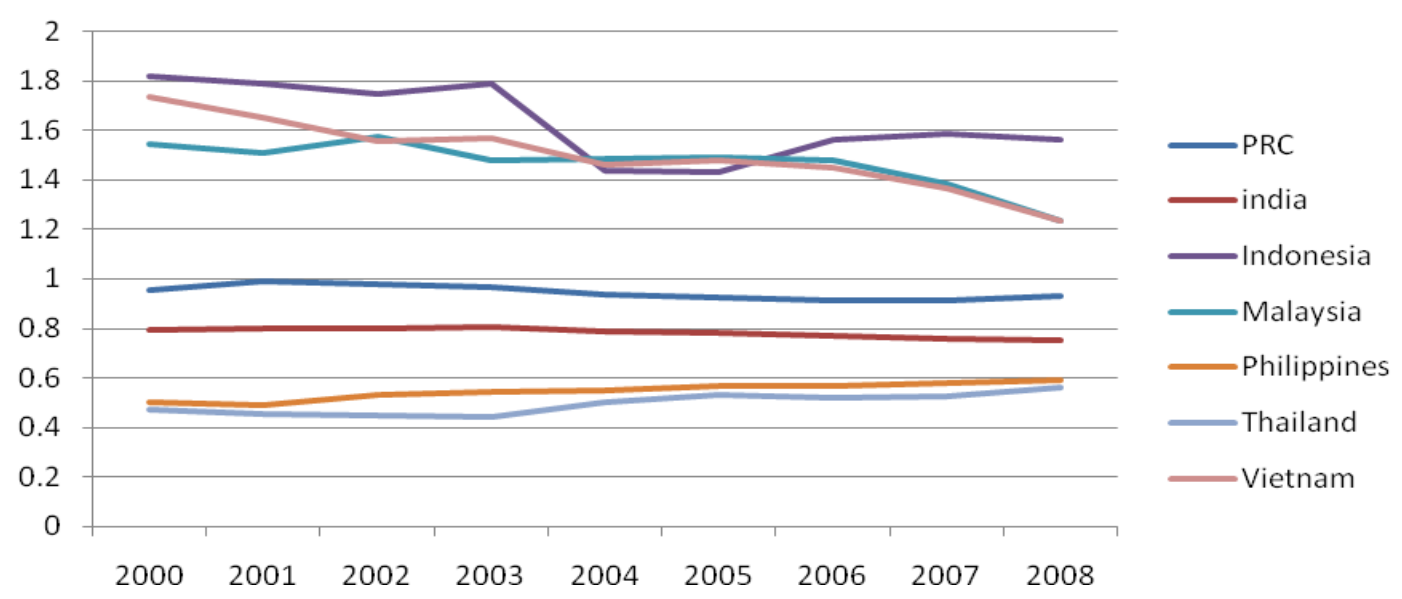

Source:EDMC (2011) and IEA (2011).

\subsubsection{Dependence on imported energy}

The dependence on imported energy is defined to be the ratio of net energy import to energy consumption.

PRC had become a net oil importer since 1993 and the dependence on imported oil continued to increase from $6.8 \%$ in 1993 to $54.2 \%$ in 2008. In 2007, PRC became a net importer of natural gas with the dependence of $1.7 \%$ in 2008.

India's dependence on imported coal has been increasing and reached $13.9 \%$ in $2008^{14}$. The dependence on imported oil has also been growing since 1984 -from $28.4 \%$ to about $73.5 \%$ in 2008. India's dependence on imported natural gas has grown rapidly since 2003 , reaching $26.1 \%$ in 2008.

In ASEAN, Singapore has the highest dependence on imported energy with total (100\%) import dependence for oil and natural gas. The Philippines's dependence on imported coal had been on a downward trend in recent years, settling at $69.4 \%$ in 2008 . However, the Philippines is highly dependent on imported oil, which reached $94.4 \%$ in 2008 . Malaysia had been completely dependent on imports since 1980 for its coal needs. During 1988 to 2007, the country's dependence on imported coal has been reducing with the lowest at $82.4 \%$. However, this was reversed in 2008 when Malaysia became completely dependent. Indonesia's dependence on imported oil has been relatively stable in recent years, registering at $18.3 \%$ in 2008. Thailand's dependence on imported coal has been growing rapidly since 1998, reaching $67.7 \%$ in 2008 . However, dependence on imported oil had declined significantly in recent years, settling at $70.6 \%$ in 2008 . Meanwhile, in terms of imported natural gas, while dependence of Thailand had been growing since 1998, it decreased from $36.3 \%$ in 2007 to $32.4 \%$ in 2008.

In the future, $\mathrm{ACl}$ countries' dependence on imported energy is expected to increase. PRC will become a net coal importer and its dependence on imported oil and gas will rise to $75 \%$

\footnotetext{
${ }^{14}$ According the presentation provided by K. Ramanathan from TERI in the latest ADB Workshop in New Delhi, India's coal import dependency will increase to be $80 \%$ in BAU scenario.
} 
and $72 \%$, respectively. Indonesia, Malaysia and Vietnam are projected to become net oil importer in 2030.

\subsubsection{Oil import diversification}

In this section, we use the $\mathrm{HHI}$ (Herfindahl-Hirschman Index) ${ }^{15}$ to measure oil market shares and to analyze the diversification of oil imports by calculating an oil import concentration index.

In 2008, oil imports of PRC reached 217.8 Mtoe, $42.2 \%$ of which were from the Middle East, $17.9 \%$ were from West Africa and $10.3 \%$ were from central Asian countries. The imports concentration of PRC has remained stable in recent years with $\mathrm{HHI}$ of 0.24 in 2008.

Total oil import of India in 2008 was 149.7 Mtoe, $71.9 \%$ of which were from the Middle East and $11.1 \%$ were from West Africa. India's imports concentration HHI was 0.53 in 2008.

In 2008, Singapore's total oil import was 130.9 Mtoe- $40.6 \%$ of which from the Middle East, 29.0\% from the Asia-Pacific region outside of India, Japan and PRC, and 6\% from south and central America. Singapore's imports concentration has been decreasing with $\mathrm{HHI}$ index of 0.27 in 2008.

Table 3.1 ACl's energy security evaluation, 2008

\begin{tabular}{|c|c|c|c|c|c|c|c|c|c|}
\hline & PRC & India & Brunei & Indonesia & Malaysia & \multicolumn{2}{|c|}{ Sigapore Philippines } & Thailand & Vietnam \\
\hline Dependence on imported oil & $54.20 \%$ & $73.50 \%$ & $0.00 \%$ & $18.30 \%$ & $0.00 \%$ & $100.00 \%$ & $94.40 \%$ & $70.60 \%$ & $0.00 \%$ \\
\hline Dependence on imported gas & $1.70 \%$ & $26.10 \%$ & $0.00 \%$ & $0.00 \%$ & $0.00 \%$ & $100.00 \%$ & - & $32.40 \%$ & $0.00 \%$ \\
\hline Dependence on imported coal & $0.00 \%$ & $13.90 \%$ & - & $0.00 \%$ & $100.00 \%$ & - & $69.40 \%$ & $67.70 \%$ & $0.00 \%$ \\
\hline HHI & 0.24 & 0.53 & - & - & - & 0.27 & - & - & - \\
\hline
\end{tabular}

- No data.

Source: IEA(2011) \& EDMC (2011) \& BP(2010); the authors analysis

A comparison of Tables 3.1 and 3.2 shows that the dependence of $\mathrm{ACl}$ economies on imported oil and gas will become significantly high in 2030, particularly for PRC ( $75 \%$ and $72 \%$, respectively), India ( $87 \%$ and $31 \%$, respectively), Malaysia and Viet Nam (from no dependence on oil to almost $45 \%$ and $73 \%$, respectively).

Table 3.2 ACl's energy security forecast, 2030

\begin{tabular}{lrrrrrrrrr} 
& PRC & India & Brunei & Indonesia & Malaysia & Sigapore Philippines & Thailand & Vietnam \\
Dependence on imported oil & $74.75 \%$ & $86.60 \%$ & $0.00 \%$ & $60.50 \%$ & $44.70 \%$ & $100.00 \%$ & $100.00 \%$ & $72.50 \%$ & $72.80 \%$ \\
Dependence on imported gas & $72.47 \%$ & $31.40 \%$ & $0.00 \%$ & $0.00 \%$ & $0.00 \%$ & $100.00 \%$ & $91.50 \%$ & $100.00 \%$ & $1.30 \%$ \\
Dependence on imported coal & $21.42 \%$ & $32.40 \%$ & - & $0.00 \%$ & $95.70 \%$ & - & $73.90 \%$ & $82.03 \%$ & $0.00 \%$ \\
& & & & & & & & & \\
Energy self-sufficency & $62.70 \%$ & $49.70 \%$ & $270.60 \%$ & $148.10 \%$ & $86.30 \%$ & $1.70 \%$ & $34.90 \%$ & $26.80 \%$ & $75.60 \%$ \\
\hline
\end{tabular}

- No data.

Source: IEA(2010) \& APERC(2009); the authors analysis

India's energy self-sufficiency is the self-sufficiency of fossil energy.

${ }^{15} \mathrm{HHI}$ (Herfindahl-Hirschman Index) is a measurement of the index of industrial concentration. It is calculated using the square sum of the proportion of each market on the total market, which presents the dispersion of market share. High HHI index indicates that the source concentrate and import risks are huge. 


\subsubsection{Transportation Security}

Crude oil is usually transported by ships, railway and pipeline. From the global perspective, more than three-fifth of crude oil is transported by ship, and less than two-fifth goes through pipeline and railway. Maritime transportation takes the lowest cost followed by pipeline transportation. However, railway is more flexible in terms of transporting various amount of energy. In case, the maritime transport is interrupted and the pipeline is not available, railway can be employed to provide oil in specific region. The international transport of natural gas is different from oil, as about three-quarters are from pipeline and one quarter is by liquefaction (LNG) marine transportation.

Currently, the $\mathrm{ACl}$ imports crude oil mainly by tankers. In PRC, more than $90 \%$ of imported oil is dependent on foreign oil tankers, especially from the Middle East and West Africa. The safety situation of main routes of the ACl's crude oil imports is not stable. These may cause supply chain risk. In view of the recent tensions in the Middle East, the current oil import channel may result in serious supply insecurity problem in the case of war, conflict, terrorism, accidents, piracy diplomatic disputes or other situations.

PRC and majority of ASEAN countries imported oil which came from the Middle East and transited through the narrow Strait of Malacca, sandwiched between the Indonesian island of Sumatra, Singapore and Malaysia. Malacca accounts for one-third of the world cargo movement by, about $50 \%$ of its oil transport capacity and also is an important gateway for offshore oil imports for Japan and South Korea. In addition, increasing volumes of LNG will pass through Southeast Asia's sea lanes from producers in the Middle East and Australia to buyers in Japan, Korea, PRC and Taiwan, China.

The narrowest width of the Strait of Malacca is just $2.7 \mathrm{~km}$, raising concerns that traffic could be disrupted by terrorism, accidents and piracy. In recognition of these risks, the three littoral states - Indonesia, Malaysia and Singapore - have been engaged in tri-partite co-operation including co-ordination of air and maritime patrols. These countries have also improved their surveillance systems and operating procedures. These measures appear to be paying off. The number of reported attempted pirate attacks dropped from 38 in 2004 to just two in 2008 and one in the first quarter of 2009 (IEA, 2009)

A number of proposals exist to bypass the congested Strait of Malacca. Two longstanding projects (now in abeyance) are (i) Thailand's proposed Kra Canal, which would cut through southern Thailand to link the Indian Ocean and the South China Sea, and (ii) Malaysia's proposed Trans-Peninsular pipeline, which would cut across Peninsular Malaysia. A more recent proposal is the PRC-Myanmar pipeline, which would reduce PRC's vulnerability to a disruption in the Strait of Malacca and also reduce shipping times from the Middle East and Africa (IEA, 2009).

\subsubsection{Energy Infrastructure Financing}

Ensuring energy security entails having the necessary infrastructure to support the efficient production, distribution and use of energy. For electricity consumption alone Bhattacharyay (2010) estimated that major $\mathrm{ACl}$ economies will require US $\$ 3,812$ billion for their infrastructure investment needs for 2010-2020. In terms of their respective GDP, this is equivalent to $3.4 \%$ or US $\$ 2773.2$ in PRC; $3.2 \%$ or US $\$ 631.7$ in India; $0.98 \%$ or US $\$ 71.8$ in Indonesia; $4.4 \%$ or 
US $\$ 124.6$ in Malaysia; $3.7 \%$ or US $\$ 130.0$ in Thailand; $1.9 \%$ or US $\$ 39.3$ in the Philippines and $3.1 \%$ or US $\$ 2.2$ in Viet Nam.

There are several challenges in financing infrastructure (Bhattacharyay, 2010). First, infrastructure projects are long-term in nature and complex in implementation. Because of this, return on investment takes a long time. There are also risks related to future costs and revenues as projects are not always economically viable or bankable. Moreover, while the government may undertake infrastructure spending, issues of fiscal deficit sustainability may limit the capacity of governments to undertake new infrastructure or maintain existing ones. Furthermore, policy, technical and institutional weaknesses hinder energy infrastructure development. Access to adequate foreign capital and risk management tools as well as efficiency and transparency in undertaking and financing projects are not adequate in most $\mathrm{ACl}$ countries.

Cross-border or regional energy projects, such as gas and oil pipelines, and energy grids in particular are very complex and time-consuming because of the sensitive nature of energy resources. A strong cooperation partnership and coordination, therefore, are needed among participating countries. ACl's regional cooperation and integration in the energy sector should be undertaken, particularly in the following areas:

(a) regional collaboration in transfer and sharing energy technologies, best practices and knowledge;

(b) regional collaboration in management of strategic petroleum and gas stocks;

(c) regional Integration of electricity and gas networks; and

(d) regional cooperation in financing for national and cross-border energy projects.

ASEAN countries have forged an agreement under the ASEAN Vision 2020 to adopt the ASEAN Plan of Action on Energy Cooperation (APAEC). The objective of this agreement is to create an ASEAN Power Grid (APG) which will connect energy projects across countries through bilateral agreements. Furthermore, ASEAN is also planning to connect gas resources through the Trans-ASEAN Gas Pipeline. An example of a successful cooperation in energy trading has been between Lao PDR and Thailand. These countries have implemented successful trade in hydropower through the Nam Theun 2 Hydroelectricity project. Because of the differences in resource endowments and needs in $\mathrm{ACl}$, energy surplus ASEAN may also extend this cooperation to energy deficit PRC and India.

At present, there are five flagship regional energy projects costing US $\$ 1.4$ billion (see Table 3.3 below). Among the regional energy projects in the Greater Mekong Subregions (GMS), comprised of a province in PRC as well as some ASEAN countries (Cambodia, Lao PDR, Thailand, Myanmar and Vietnam), around $50 \%$ of the investments are needed for Lao PDR.

Table 3.3: High Priority "Flagship" Regional Projects for Energy

\begin{tabular}{|c|c|}
\hline Energy Projects & $\begin{array}{c}\text { Cost } \\
\text { (in US \$ million) }\end{array}$ \\
\hline Total & 1,414 \\
\hline 1. GMS Northern Power Transmission & 54 \\
\hline 2. GMS Nabong-Udon Thani Power Transmission & 110 \\
\hline
\end{tabular}




\begin{tabular}{|cc|}
\hline and Interconnection & \\
3. Lao PDR-Viet Nam Power Interconnection (Ban & 270 \\
Sok-Pleiku) & 380 \\
4. GMS Nam Ngiep 1 Hydropower Project & 600 \\
5. GMS Nam Ngum 3 Hydropower Project & \\
\hline
\end{tabular}

Source: Bhattacharyay (2010) and ADB/ADBI (2009)

Increased regional cooperation can allow $\mathrm{ACl}$ make use of their excess savings and large foreign exchange reserves for national and regional energy infrastructure investment. $\mathrm{ACl}$ can undertake appropriate investment and trade treaties which will facilitate cross-border flow of investment. Potential sources of funding include:

- Public Funding: Economic Stimulus Packages,

- Pan-Asian and Sub-regional Infrastructure Banks/Funds,

- Multilateral Development Banks and Bilateral Agencies,

- Capital Markets: Local Currency Bond Markets,

- Regional Infrastructure Companies for Financing Specific Sectors, and

- Sovereign Wealth Funds

- Islamic Funds.

Infrastructure development is a very important component of energy security. On one hand, for achieving sustainability, we need to take energy efficiency and $\mathrm{CO} 2$ emission into consideration when building and operating energy infrastructure. On the other hand, we also need to develop adequate energy infrastructure to provide abundant supply of energy and thus enhance energy security, particularly in the electricity sector.

\section{Conclusions}

Although the $\mathrm{ACl}$ economies are projected to experience tremendous economic growth in the coming decades, their sustainable growth and quality of life are also tied to the availability of key resources, particularly green, renewable and clean energy. Even with the significant conservation measures, the ACl's demand for energy is expected to see a phenomenal rise leading to serious energy security and environmental challenges (see Tables 3.1, 3.2 and 4.1):

(i) The primary energy demand of ASEAN, the PRC and India in 2030 will almost double in comparison with 2009 (2007 for ASEAN).

(ii) As a result of huge energy demand and a carbon-intensive fuel mix by 2030, CO2 emissions of ASEAN, the PRC and China will increase by 2 times; and

(iii) The dependence of $\mathrm{ACl}$ economies on imported oil and gas will become significantly high in 2030, particularly for PRC (75\% and 72\%, respectively), India (87\% and 31\%, respectively), Malaysia and Viet Nam (from no dependence on oil in 2008 to almost $45 \%$ and $73 \%$, respectively).

Table 4.1: Energy Demand and Carbon Dioxide Emissions

\begin{tabular}{|c|c|c|c|c|c|c|}
\hline \multirow{2}{*}{$\begin{array}{l}\text { Region or } \\
\text { Country }\end{array}$} & \multicolumn{3}{|c|}{$\begin{array}{c}\text { Total Primary Energy Demand } \\
\text { (Mtoe) }\end{array}$} & \multicolumn{3}{|c|}{$\mathrm{CO}_{2}$ Emissions (million tons) } \\
\hline & 1990 & 2009 & 2030 & 1990 & 2009 & 2030 \\
\hline ASEAN* & 243 & $513(2007)$ & 988 & 361 & $\begin{array}{r}1,013 \\
(2007)\end{array}$ & 2,079 \\
\hline PRC & 872 & 2,271 & 4,320 & 2,244 & 6,877 & 13,290 \\
\hline India & 319 & 669 & 1,256 & 593 & 1,548 & 3,004 \\
\hline
\end{tabular}

ASEAN = Association of Southeast Asian Nations, $\mathrm{CO}_{2}$, carbon dioxide, Mtoe = million tons of oil equivalent, PRC = People's Republic of China.

*2009 data for ASEAN is not available. 2007 data has been used.

Source: 1990, 2007 and 2009 figures from IEA (2009) and IEA (2011b); and 2030 figures from authors' analysis 
. Adopting sustainable and innovative management practices and policies for key resources (such as energy) and mitigating environmental degradation and climate change problems are among major common challenges for all the $\mathrm{ACl}$ economies. Unless these problems are addressed, these trends will amplify global environmental risks, energy security and geopolitical strains. Before moving on to providing policy recommendations, the next part of the section discusses the key features of ACl's energy security outlook.

\section{1 $\mathrm{ACl}$ region dominates the energy security challenges in whole Asia}

The $\mathrm{ACl}$ region is the core of Asian energy production and consumption as it consumes and produces the bulk of Asia's energy. In 2008, energy consumption in ACl region accounted for $92 \%$ of the Asia's consumption, while energy production was 95\% of Asia's production. Coal, oil and natural gas consumption of $\mathrm{ACl}$ accounted for $96 \%, 89 \%$ and $80 \%$ respectively and production of coal, oil and natural gas were $99 \%, 98 \%$ and $87 \%$ of those of Asia (EDMC, 2011 and IEA, 2011Aa). Most of ACl's coal export and almost all of the natural gas exports flow inside Asia, which provides important safeguard to Japan, Korea, and other Asian countries.

\subsection{Energy security in $\mathrm{ACl}$ is an important challenge}

Energy self-sufficiency in most $\mathrm{ACl}$ countries will decline through 2030 and their dependence on imported energy will increase. By 2030, PRC's energy self-sufficiency will decline to $62.7 \%$, and the country will become a net coal importer whereas India's dependence on imported energy will rise and energy self-sufficiency will decline to $49.7 \%$. In ASEAN countries, only Brunei remains fully energy self-sufficient. Indonesia, Malaysia and Vietnam will turn into net oil importer by 2030 .

\subsection{Oil security in $\mathrm{ACl}$ is the most serious issue in regional energy security}

Among energy supply, coal and natural gas are expected to last a long time in the future. However, oil supplies depend on imports and nearly all the $\mathrm{ACl}$ countries import more than half of their oil, except Malaysia, Vietnam and Brunei. In the future, with the decrease of oil production in Indonesia, Malaysia and PRC, the internal supplies of oil is expected to become more pressing in the future. The dependence on imported oil of the $\mathrm{ACl}$ region is getting stronger. Due to the excessive dependence on imports, oil importers will be greatly influenced by oil price rising. The impact may transmit along supply chain to all sectors in the economy and increase the risk of imported inflation. Establishing national and regional oil reserves can reduce the risk caused by oil price rising. Release of oil reserves when necessary can safeguard oil supply and reduce economic losses. However, since 2014 oil price has witnessed significant downward movement decreasing pressure on large imports by oil-deficit $\mathrm{ACl}$ economies. The landmark agreement on Iran nuclear program and subsequent removal economic sanctions may ease the $\mathrm{ACl}$ energy security challenge.

\section{4 $\mathrm{ACl}$ countries have the risk of supply disruption due to complex geopolitical conditions}

Major oil importing countries in the $\mathrm{ACl}$ region such as PRC, India and Singapore import more than half of crude oil from the Middle East. In addition, imported oil from the Middle East must pass through the Strait of Malacca, and this makes $\mathrm{ACl}$ countries face greater risks, such as military threat and blockade, conflict, terrorist acts, piracy, transnational crimes etc. The 
single import source and transportation corridor will increase the risk of supply disruption on importing countries. A closer cooperation on protecting the transportation channel safety among $\mathrm{ACl}$ countries is needed. Joint management of maritime transport channels, such as jointly fighting against terrorist acts, and piracy, can guarantee the oil transportation security of the $\mathrm{ACl}$ region.

In addition, $\mathrm{ACl}$ countries should strengthen their relationship with oil producing country to guarantee consistent supply of oil. On one side, the $\mathrm{ACl}$ countries should actively carry out diplomatic activities with these countries. On the other side, encouraging cooperation between enterprises is also crucial. The enterprises of $\mathrm{ACl}$ countries can conduct joint research and development on energy technologies with enterprises in oil producing countries. Enterprises of $\mathrm{ACl}$ countries can also participate in energy exploration in oil producing country to get their share of oil and gas. This will not only improve the stability of energy supply, but also strengthen the interdependence between and among the countries.

\subsection{India, Singapore, the Philippines, PRC and Thailand have more serious energy security problems in $\mathrm{ACl}$ region}

In India, Singapore, the Philippines and Thailand, more than two-third of oil supplies depend on imports. In addition, India's import concentration on imported oil is extremely high while the Philippines and Thailand depend greatly on coal imports. High dependence on imports and a huge amount of oil needs will make the PRC's oil security problem more serious. Due to the production limitation and fast growth of demand, the supply gap is expected to become greater in the future and the dependence on imports oil will increase. At present, Brunei and Vietnam are only two countries in the $\mathrm{ACl}$ region which can fully meet their own energy demands. For $\mathrm{ACl}$ countries, their energy security situation can be improved through promoting domestic energy conservation and improving energy efficiency policies, developing new energies, and optimizing energy production and distribution structure, among others.

\subsection{Regional cooperation among $\mathrm{ACl}$ countries is of importance}

$\mathrm{ACl}$ countries are neighbors. Their economies are dependent one each another, therefore, it is necessary to cooperate based on the win-win principle. If oil flows among $\mathrm{ACl}$ countries are excluded from international oil trade, ACl's dependence on imported oil will decrease to $54 \%$, from existing level of $59 \%$. Hence, it is of no doubt that $\mathrm{ACl}$ cooperation will provide each country with significant benefit.

$\mathrm{ACl}$ countries also can reduce the cost of developing alternative technology through regional joint development of new energy and technical exchanges to improve their energy security situations. Joint development of regional energy projects like those of GMS can also improve energy supply. In addition, establishing an $\mathrm{ACl}$ joint oil emergency system like International Energy Agency (IEA) member countries can strengthen $\mathrm{ACl}$ regional energy security.

Enhanced regional cooperation will be required for further integration of national energy markets of $\mathrm{ACl}$ as well as major oil producing countries and utilization regional financial and technical resources for developing energy infrastructure and connectivity,

\subsection{Policy Recommendations for a sustainable energy security outlook}

Achieving the ACl's sustainable energy security is not going to be easy and will require a concerted and coordinated effort on behalf of policy makers across many fields and a strong 
partnership with private sectors. One of the key issues which need to be addressed urgently is the effectiveness of policy formulation and implementation. This calls for institutional strengthening at the country and regional levels. However, in terms of the social, institutional, economic and policy context, each of the $\mathrm{ACl}$ economies differs. There is an urgent need for regional cooperation for ensuring the ACl's energy security in the coming decades. For an effective implementation of the policy recommendations at the national and regional levels, the factors that need to be considered are discussed below.

- Translation of national goals in order to enable wider access to energy services and resource efficient technologies needs to be strategized through innovative policies, financing schemes and the strong participation of various stakeholders;

- As major energy consumers of the world, PRC, India and Indonesia need to pursue greater coordination with other major oil importers through the IEA, of which they are not yet members. Therefore, these countries need to join the IEA and build greater multilateral regional engagement with other Asian countries to secure regional and own energy demand (Drysdale, 2011).

- Widening access to energy services for the poor may lead to an overall increase in energy consumption for some countries. However, such energy can be brought from off-grid renewable sources. Utilizing the energy efficiency potential in many of these countries, particularly in urban areas, could go a long way towards offsetting this possible increase in consumption;

- It is important to quantify resource efficiency and renewable energy potential at the national level in order to assess the implications for (i) energy security; (ii) emission reduction; and (iii) a country's competitiveness;

- More innovative financing schemes at the micro- and macro levels will be needed in order to implement strategies for access to energy services and fostering energy efficiency. A mechanism to complement these strategies-through closer links to the emerging carbon market and domestic financing schemes-needs to be developed at the national level.

- For ensuring energy security and efficiency, the $\mathrm{ACl}$ countries need to enhance their regional cooperation particularly in sharing (i) cross-border energy resources (through integration of energy markets across the region); (ii) financial resources to meet regional financing needs for developing energy infrastructure and connectivity; and (iii) knowledge, best practices and know-how.

Achieving sustainable energy security will involve coherent efforts by many actors, national and sub-national governments, private sectors, international development organizations, and knowledge institutes. The following concrete policy options could help countries take advantage of the opportunities available for achieving energy security:

- Develop large national and cross-border energy projects involving hydro, nuclear, solar and wind power which can reduce electricity generation from coal and oil and thus limit environmental damage.

- Employ market-based instruments to improve eco efficiency in resource use and promote innovations in renewable energy technology. Placing a price on emissions and pollutions has been found to stimulate innovation as firms and consumers seek out clean and green alternatives. Environmental and energy related taxation on some level, has been successfully used by countries around the region since 1970s and 1980 including PRC, Malaysia, the Philippines and Thailand.

- Establish well designed regulatory frameworks for the energy sector that can define right conditions for market based instruments and create incentives as well as remove barriers for investments in renewable energy resources. Adequate regulatory frameworks such as feed-in-tariffs can reduce business risks and increase confidence.

- Prioritize government investments and spending in areas that stimulate the energy conservation as well as pollution prevention. Green subsidies such as price support measures, tax incentives, direct grants and loan support may be used to avoid lock in effects as well as foster new industries in energy, and emission reduction sectors, as a part of combined $\mathrm{ACl}$ strategy to build comparative advantage and drive long term employment growth. 
- Limit government spending in areas that deplete resources. Artificially lowering the cost of using fossil fuels through subsidies is deterring consumers and industries from adopting resource efficient measures that would otherwise be cost effective. Though subsidy reform is possible in $\mathrm{ACl}$, it is challenging given the vested interest in their maintenance. However, there are several alternatives of fuel subsidy such as conditional cash transfer schemes where aid is targeted to poor households. In view of the recent sharp drop in oil prices, it may be possible to reduce fuel subsidy significantly.

- Set up a regional platform to encourage REDD (reduced emissions from deforestation and degradation) projects and push for reforms to the rules governing the United Nations Framework Convention on Climate Change (UNFCC) mechanisms and forest preservation. This platform should be hosted by key forest nations of the region and involve the international community, regional financial institutions, civil society and the private sector.

The energy security is closely linked to water and food security. ACl economies need to formulate a comprehensive long-term sustainable energy security plan at the national and regional levels linked to the water and food security plans.

\section{Bibliography}

Asian Development Bank (ADB), and ADB Institute, 2009. Infrastructure for a Seamless Asia, ADB Institute, Tokyo.

Asian Development Bank (ADB), 2009. Energy Outlook for Asia and the Pacific. Manila, Philippines.

ADB (2011a), Background Note, World Water Week: Eye on Asia, Stockholm, Sweden : 23 August 2011, available at http://www.adb.org/news/events/world-water-week-eye-asia-2011 ADBI (2011b). Measuring Asia's Progress towards Tackling Climate Change and Accelerating Green Growth, Proceedings of the workshop for ADB/I Study on Climate Change and Green Asia, New Delhi, September.

APERC, 2009. APEC Energy Demand and Supply Outlook 2009. Tokyo, Japan.

APERC, 2010. Pathways to Energy Sustainability: Measuring APEC Progress in Promoting

Economic Growth, Energy Security, and Environmental Protection. Tokyo, Japan.

APERC and ADB, 2009.Energy Outlook for Asia and the Pacific. Manila, Philippines.

Bentham, Jeremy, 2011. Water, Energy and Food Security in the Urban Context - the Role of Business. Presented in World Water Week, August 21-21, 2007, Stockholm.

Bhattacharyay, Biswanath, 2010. Estimating Demand for Infrastructure in Energy, Transport, Telecommunications, Water and Sanitation in Asia and the Pacific: 2010-2020. Working Paper No: 248. ADBI, Tokyo.

British Petroleum (BP), 2010. BP statistical review of the world energy. London, UK.

Coal Network, 2010.

Cline, William, R., 2007. Global Warming and Agriculture: Impact Estimates by Country, Peterson Institute for International Economics, Washington, DC, September 12.

Dixon, Peter B. and Rimmer, Maureen T., 2002. Dynamic, General Equilibrium Modelling for Forecasting and Policy: a Practical Guide and Documentation of MONASH, North-Holland, Amsterdam.

EDMC, 2011. APEC Energy Database. Energy Data and Modeling Centre, Institute of Energy Economics, Tokyo, Japan.

EIA, 2010a. China Energy Data, Statistics and Analysis - Oil, Gas, Electricity, Coal. US.www.eia.doe.gov. 
EIA, 2010b. India Energy Data, Statistics and Analysis - Oil, Gas, Electricity, Coal. US. www.eia.doe.gov.

EIA, 2010c. Indonesia Energy Data, Statistics and Analysis - Oil, Gas, Electricity, Coal. US. www.eia.doe.gov.

EIA, 2010d. Malaysia Energy Data, Statistics and Analysis - Oil, Gas, Electricity, Coal. US. www.eia.doe.gov.

IEA, 2011a. Energy Database: 1971-2008. International Energy Agency, Paris, France. http://www.iea.org/.

IEA, 2009. World Energy Outlook 2009. Paris, France.

IEA, 2010. World Energy Outlook 2010. Paris, France.

IEA, 2011b. World Energy Outlook 2011. Paris, France.

IEA, 2011c. Are We Entering A Gold Age of Gas? World Energy Outlook 2011 Special Report. Paris, France.

Hoekstra, A.Y. 2003. Virtual Water Trade Available: http://www.waterfootprint.org/Reports/Report12.pdfhttp://beta.adb.org/news/events/worldwater-week-eye-asia-2011)

Kemfert, C., Welsh, H., 2000. Energy-Capital-Labor Substitution and the Economic Effects of $\mathrm{CO}_{2}$ Abatement: Evidence for Germany. Journal of policy Modeling, 22, 641-640.

2050 PRC Energy and Carbon Emissions Task Force. 2009. 2050 PRC Energy and $\mathrm{CO}_{2}$ Emissions Report. The Science Press, Beijing, PRC. (in Chinese)

UNPD, 2009. World Population Prospects: The 2008 Revision. UNPD, New York.

UNPD, 2010. World Urbanization Prospects: the 2009 Revision. UNPD, New York.

Zhang, Zhongxiang. 1996. Integrated Economy-Energy-Environment Policy Analysis: A case Study for the People's Republic of China. Ph.D. dissertation, University of Wageningen, The Netherlands.

Zhang, Zhongxiang, 1998. Macroeconomic Effects of $\mathrm{CO}_{2}$ Emissions Limits: A Computable General Equilibrum Analysis for China. Journal of Policy Modeling, 20, 213-250.

Zhao, Hong, 2009. China and India: The Energy Policies. EAl Background Brief No. 462. 